\title{
A review of the taxonomic history and biodiversity of the genus Urodeta (Lepidoptera: Elachistidae: Elachistinae), with description of new species
}

\author{
JURATE DE PRINS ${ }^{1} \&$ VIRGINIJUS SRUOGA ${ }^{2}$ \\ ${ }^{1}$ Royal Museum for Central Africa, Leuvensesteenweg 13, B-3080 Tervuren, Belgium.E-mail: jurate.de.prins@africamuseum.be. \\ Corresponding author. \\ ${ }^{2}$ Lithuanian University of Educational Sciences, Studentu 39, LT-08106 Vilnius, Lithuania. E-mail: virginijus.sruoga@vpu.lt.
}

\begin{abstract}
The taxonomic history of the genus Urodeta Stainton 1869 (Lepidoptera: Elachistidae: Elachistinae) is presented. Three new species: Urodeta acinacella Sruoga et De Prins, sp. nov., U. quadrifida Sruoga et De Prins, sp. nov. and $U$. trilobata Sruoga et De Prins, sp. nov., from South Africa are described. The new species are diagnosed and illustrated with photographs of the adults and genitalia. A global, annotated catalogue of the Urodeta species diversity is presented. The impact of formerly published taxonomic decisions on the position of Urodeta within Gelechioidea is discussed.
\end{abstract}

Key words: Lepidoptera, Elachistidae, Elachistinae, Urodeta, new species, South Africa

\section{Introduction}

The apoditrysian family Elachistidae, including its subfamily Elachistinae, has recently gained a comprehensive phylogenetic treatment (Kaila 1999, 2004; Kaila \& Sugisima 2011, Kaila et al. 2011) culminating with a landmark monograph on the biodiversity of its Australian fauna (Kaila 2011). However, sub-saharan Africa still remains as one of the major sources for new discoveries especially in fragmented and restricted microhabits suitable for the elachistine fauna (Landry 2011). The enigmatic genus Urodeta Stainton, 1869 serves as one of the best examples illustrating that the exploration of the elachistine diversity in sub-saharan Africa might significantly change our understanding of the global elachistine diversity pattern as well as the phylogeny of these moths. It may perhaps also reflect more generally the current state of knowledge on small-sized moths in tropical and other less comprehensively explored regions. The aim of this paper is to review the controversial taxonomic history of Urodeta Stainton, 1869, its species diversity and to describe three new Urodeta species from sub-saharan Africa.

\section{Historical review}

Based mainly on life history and pupal characters, Stainton (1869) described the genus Urodeta and indicated its closeness to Elachista (for a detailed re-description refer to Kaila 2011: 45; for the generic characters applicable to the Afrotropical Urodeta taxa, refer to Sruoga \& De Prins 2011: 3-4). For ca. 140 years Urodeta was considered a Mediterranean monotypic genus. The generic concept in the early 19th century was different from the present practice and the generic name Elachista introduced by Treitschke (1833) meant more 'small moths' in general than a monophyletic or closely related species group (Kaila 2011). However, even at that time, the awareness among lepidopterists was growing to classify the lepidopteran taxa according to their 'natural' groupings (Zeller 1848; the series of 'Natural History of Tineina' by Stainton (1855, 1857, 1858a, 1859, 1860, 1861, 1862, 1864, 1865, 1867, 1870a,b, 1873), assisted by Zeller, Douglas and Frey. Therefore, the initial placement of Urodeta close to Elachista was made by Stainton based on a thorough knowledge of the natural history of both genera. Meyrick (1881) followed this trend and was very attentive to the biological characters while suggesting his classification of micro moths. Regarding Urodeta and its relatives, Meyrick (1881: 133) wrote the following: "There are however a few 
very small genera (Tischeria, Bedellia, Urodeta, Arctocoma (described hereafter) [in Meyrick 1881], and perhaps Oenophila, of which the larva is hardly known) which are sometimes referred to the Lithocolletidae, and sometimes to the Elachistidae but do not agree with either, being separated from the former by the sixteen-legged larvae, and from the latter by the roughly tufted head. I would place these in a separate family, which I have below called Bedellidae, a step which appears to me to be in accordance with nature, and to simplify the systematic discrimination of the families". However, Edward Meyrick probably examined misidentified adult specimens of what he thought belonged to Urodeta: the scales in Urodeta are appressed to the head, i. e. the head is "smooth" (see Kaila 2011: fig. 11; Sruoga \& De Prins 2011: figs 14, 24, 34, 38, 51, 57, 65, 73, 84). Rebel (1901) was very clear regarding the taxonomic position of Urodeta; he placed this genus [no 418 in the numeric system of the catalogue] into the family Elachistidae and in the subfamily Elachistinae together with the genera Atachia Wocke, [1876] [no. 414], Perittia Stainton, 1854 [no. 415], Stephensia Stainton, 1858(b) [no. 416], Elachista Treitschke, 1833 [no. 417] and Scirtopoda Wocke [1876] [no. 419].

As we see from the further taxonomic history of Urodeta, the misidentified specimens used by Edward Meyrick (1881) which had a rough head (and which Meyrick called Bedellidae) caused a confusion for over a century. Following the publication of Meyrick (1881), Fletcher (1929) referred Urodeta to Lyonetiidae. Lhomme (1946-1963) examined the (correctly identified) specimens of $U$. cisticolella in the collections of de Joannis, Stainton, Ragonot, Chrétien, Dumont and Parsonneau (the detailed list of the localities and depository of the examined Urodeta specimens can be found on p. 869 of Lhomme's work) as well as the Urodeta mines in the collection of Millière on Cistus monspeliensis L. and C. salviaefolius L. Lhomme followed Stainton, Staudinger and Rebel by placing the genus Urodeta, preceded by Elachista, in Elachistidae. While reviewing the Lepidoptera of Portugal, Zerkowitz (1946) also considered Urodeta as an elachistid genus, indicating Cistus $\times$ ledon Lam. and C. ladaniferus Stokes as the host plants of U. cisticolella. However, Leraut (1980: 73) included Urodeta in Momphidae, referring to a letter of Ebbe Schmidt Nielsen who considered that this genus could best be placed in that family (Leraut 1980: 195). Although Patrice Leraut corrected this misplacement in the second edition of his catalogue (Leraut 1997: 107), returning Urodeta to Elachistidae and placing it together with Perittia in Elachistinae: Perittini, the misplacement of Urodeta in Momphidae published in the first edition (Leraut 1980) was unfortunately repeated in subsequent publications by other authors. Thus, Nye \& Fletcher (1991) listed Urodeta as a genus of Momphidae, followed by Vives Moreno (1991, 1994); the same point was taken by Riedl (1996), indicating the synonymy of the type species for the first time. Ole Karsholt and Bengt Bengtsson discovered that the type species Urodeta cisticolella Stainton 1869 is a junior subjective synonym of Butalis hibernella Staudinger, 1859: "Fresh specimens of Urodeta cisticolella Stainton, 1869 kept in ZMUC [Copenhagen] were found identical to the type specimen of hibernella preserved in ZMHB [Berlin] and which is in good shape although the abdomen is missing" (Bengtsson 1997: 208). No family name was mentioned in the original description of Butalis hibernella by Staudinger (1859).

\section{Original description of Butalis hibernella Staudinger, 1859}

\section{"112. Butalis Hibernella.}

Palpis brevioribus; alis anterioribus fusco - cinereis; alis posterioribus griseis. $7925 \mathrm{~m}$.

Vorderflügel dunkel aschgrau; Hinterflügel äusserst schmal, grau. Palpen sehr klein, wodurch diese Art wesentlich von $B$. Incongruella, die auch viel grösser ist, abweicht.

Ein $\precsim$ am 26. Februar bei Chiclana.”

Staudinger clearly indicated that the palpi in hibernella are very small and the hindwings are very narrow - these characters fully correspond to all species of Urodeta (Sruoga \& De Prins 2011). He also mentioned that hibernella significantly deviated from the other widely distributed European gelechioid Amphisbatis incongruella (Stainton, 1849). However, Staudinger placed his new Andalusian (south of Spain) species in Butalis Treitschke, 1833 (moths), a name which is a junior homonym of Butalis Boie, 1826 (birds). Rebel (1901: 181) assigned hibernella [no 3469 in the numeric system of the catalogue] to Scythris but placed this species in Elachistidae. The current valid name of Butalis Treitschke, 1833 is Scythris Hübner, [1825], included in the Scythrididae (van Nieukerken et al. 2011).

In the original description of Urodeta Stainton (1869: 226) wrote the following: "The neuration I have not investigated". This was done by Bengtsson 128 years later (1997: fig. 419), and he found that it corresponds with that of a scythridid but "other features are very atypical (hair scaling, labial palps etc.)" (Bengtsson 1997: 208, pl. 
14: fig. 15). The position of Urodeta as a genus in Momphidae was taken over by the online checklist 'Fauna Europaea' and remained there in version 2.4 as well (Karsholt \& van Nieukerken 2011). The placement of Urodeta among momphids was kept by Hodges (1998), though all this group of moths was presented as the subfamily Momphinae in the family Coleophoridae. Kaila (1999) in his phylogeny and classification of the Elachistidae s. s. did not include Urodeta in his treatment, as he thought that this formerly monotypic genus belonged to Momphidae (Kaila \& Sugisima 2011). Koster \& Sinev (2003: 195) were very clear in accepting the later opinion of Leraut (1997). They wrote the following: "Leraut (1997), however, again placed Urodeta in Elachistidae, stating that 'this genus is a truly primitive member of the Elachistinae related to the genus Perittia (Leraut \& Minet, in prep.)'. Kaila (pers. comm.) agrees that hibernella belongs to Elachistidae in the broad sense, but not to Elachistinae".

In the phylogeny of Gelechioidea, based on morphological characters, Kaila (2004: 306) tabulated Urodeta hibernella (Staudinger, 1859) as a species belonging to Coleophoridae: Momphinae, yet in the strict consensus cladogram on p. 312 he placed Urodeta hibernella in the same clade as Elachista adscitella+E. gerasmia, i.e. Elachistidae: Elachistinae. Moreover, in the latest phylogeny of elachistine moths based on morphological characters Kaila \& Sugisima (2011: 8) stated unambiguously that "The Elachistinae are now considered to comprise four genera: Urodeta, Perittia, Stephensia and Elachista". Three species of Urodeta were used for the morphological phylogenetic analysis: U. inusta Kaila, 2011, U. hibernella (Staudinger, 1859) and U. sp. 'terminaliae' [Note: this specific indication is not in accordance with the ICZN (1999), therefore, in our further treatment we shall call it Urodeta sp. reared from Terminalia sp.]. In the cladogram of synapomorphies presented by Kaila \& Sugisima (2011: 19, table 4) Leraut \& Minet's observation of Urodeta as 'a truly primitive member of the Elachistinae' is reiterated (Koster \& Sinev 2003: 195). Unfortunately, the recent phylogeny of the Gelechioidea based on molecular characters (Kaila et al. 2011) does not present the phylogenetic position of Urodeta.

The genera Myrrhinitis and Phthinostoma were excluded from Elachistidae by Parenti (1988) without proposing another placement. This taxonomic act was made referring to the doubts expressed by Lajos Vári in his answer to Umberto Parenti (Parenti 1988: 187): "Your query [of Umberto Parenti] on the eventual family of the species Myrrhinitis sporeuta Meyr. and the genus Phthinostoma present a difficult problem. Although I [Lajos Vári] know the southern African micros families fairly well, I cannot place the above species in any other family to give a more satisfactory grouping". Aware of the substantial differences one finds in trying to place African microlepidopterans into families that were traditionally based on the European fauna Vári was very careful not to propose any taxonomic act for those two Afrotropical genera that were mentioned in his letter. In fact, his letter does not rule out that the genera Myrrhinitis and Phthinostoma might belong to Elachistidae: Elachistinae. Phrasing his reply to Umberto Parenti with care, Lajos Vári clearly implied that the status of these genera needed revision. Vári did not accept the synonymization of Symphoristis ptychospila Meyrick 1918 with Elachista nimbifera Meyrick 1913 proposed by Parenti (1988: 193), unambiguously indicating in his later publication (Vári et al. 2002: 40), that Cleroptila Meyrick, 1914a, Cryphioxena Meyrick, 1921, Elachista Treitschke, 1833, Mendesia de Joannis, 1902, Myrrhinitis Meyrick, 1913, Phthinostoma Meyrick, 1914b, Proterochyta Meyrick, 1918, and Symphoristis Meyrick, 1918 are valid genera of Elachistidae: Elachistinae. According to Mey (2007: 21), the scobinate gnathos of males in Phthinostoma "is probably the key feature for placing Phthinostoma in Gelechioidea". Both Phthinostoma species described from Namibia, P. maculata Mey, 2007 and P. taeniata Mey, 2007, were transferred to Urodeta by Kaila \& Sugisima (2011), and presently belong to Elachistidae: Elachistinae. Kaila \& Sugisima (2011) found that, based on three synapomorphies and three homoplastic characters of Perittia, Phthinostoma infumata Meyrick, 1914 (the type species of its genus) nests within Perittia. Thus Perittia infumata (Meyrick, 1914) as well as Perittia pachyzona (Meyrick, 1921), also formerly a Phthinostoma, were transferred to Elachistidae: Elachistinae (Kaila \& Sugisima 2011: 18).

It seems reasonable at the moment not to ignore but to follow the original suggestion of Meyrick, supported by Vári (Vári et al. 2002), and consider the above mentioned genera as belonging to Elachistidae: Elachistinae until additional morphological and/or molecular data suggest an alternative position. At present data totalling 5466 base pairs (1476 bp of mitochondrial cytochrome oxidase subunit I gene (COI), $1047 \mathrm{bp}$ of the elongation factor-1 $\alpha$ (EF-1 $\alpha$ ), 603 bp of the ribosomal protein S5 (RpS5), 865 bp of the carbamoylphosphate synthase domain protein (CAD), $407 \mathrm{bp}$ of the cytosolic malate dehydrogenase (MDH), $722 \mathrm{bp}$ of the isocitrate dehydrogenase (IDH) and $346 \mathrm{bp}$ of the wingless genes from the nuclear genome) are available for three genera: Elachista Treitschke, 1833, Perittia Stainton, 1854 and Stephensia Stainton, 1858 (Kaila et al. 2011), out of seven described, and by different authors recognized as valid genera belonging to Elachistidae: Elachistinae (see Table 1). There is a great need for thorough studies, both morphological and molecular, on the phylogenetic position of Urodeta and its relationship to other elachistine genera, especially to its tropical relatives. 
TABLE 1. Elachistine genera recognized as valid in the period 2002-2011 (Vári et al. 2002; Kaila 2004; Pitkin \& Jenkins 2004; Beccaloni et al. 2005; Sruoga \& De Prins 2009, 2011; Kaila \& Sugisima 2011; De Prins \& De Prins 2012)

1. Cryphioxena Meyrick, 1921

“Cryphioxena n. g."-Meyrick, E. 1921. Annals of the Transvaal Museum 8: 123 [originally described in Plutellidae].

Type species: Cryphioxena haplomorpha Meyrick, 1921 by monotypy.

"Cryphioxena haplomorpha n. sp."-Annals of the Transvaal Museum 8: 123.

2. Elachista Treitschke, 1833

"Genus CLIII. ELACHISTA"-Treitschke, F. 1833. Die Schmetterlinge von Europa 9(2): 177.

Type species: Elachista bifasciella Treitschke, 1833 by subsequent designation by Meyrick, 1915 .

“9. BIFASCIELLA"-Treitschke, F. 1833. Die Schmetterlinge von Europa 9(2): 182-183.

3. Eretmograptis Meyrick, 1938

"ERETMOGRAPTIS n. g."-Meyrick, E. 1938. Exploration du Parc National Albert, 14: 21-22.

Type species: Eretmograptis coniodoxa Meyrick, 1938 by monotypy.

“68-Eretmograptis coniodoxa n.sp.”-Meyrick, E. 1938. Exploration du Parc National Albert 14: 22.

4. Myrrhinitis Meyrick, 1913

"Myrrhinitis, n. g."-Meyrick, E. 1913. Annals of the Transvaal Museum 3: 322.

Type species: Myrrhinitis sporeuta Meyrick, 1913 by monotypy.

"Myrrhinitis sporeuta, n. sp."-Annals of the Transvaal Museum 3: 322.

5. Perittia Stainton, 1854

“Genus V. PERITTIA, n.g.”-Stainton, H.T. 1854. Insecta Britannica: 177.

Type species: Aphelosetia obscurepunctella Stainton, 1848 by monotypy.

"Sp. 1. OBSCUREPUNCTELLA, Stainton"-Stainton, H.T. 1848. Zoologist 6: 2164.

6. Stephensia Stainton, 1858

"STEPHENSIA, n. g."-Stainton, H.T. 1858b. The Transactions of the Entomological Society of London, n. s. 4: 269-270.

Type species: P.[halaena] Tinea brunnichella Linnaeus, 1767 by monotypy.

"Brunnichella 448. P. Tinea"-Linnaeus, C. 1767. Systema Naturae (12th Edition) 1(2): 898.

\section{Urodeta Stainton, 1869}

"Urodela, [recte Urodeta] n. g."-Stainton, H.T. 1869. The Tineina of Southern Europe: 226.

Type species: Urodeta cisticolella Stainton, 1869 by monotypy.

“cisticolella, n. sp.”- Stainton, H.T. 1869. The Tineina of Southern Europe: 226.

Note: Proterochyta Meyrick, 1918 is transferred to Scythrididae by Parenti (1988: 188)

"Proterochyta n.g."-Meyrick, E. 1918. Annals of the Transvaal Museum 6: 56.

Type species: Elachista epicoena Meyrick, 1914 by original designation and monotypy.

"Elachista epicoena, n. sp."-Meyrick, E. 1914b. Annals of the Transvaal Museum 4: 196.

Vári et al. (2002: 40) reinstalled Proterochyta Meyrick, 1918 back to Elachistidae. After examining the genitalia of the type specimen of P. epicoena (Meyrick, 1914) by several Gelechioidea specialists the assessment of Parenti (1988) was confirmed. The genus Proterochyta Meyrick, 1918 and its type species Elachista epicoena Meyrick, 1914 were included in the Scythrididae by Passerin d'Entrèves \& Roggero (2007:11) in their world catalogue of the family. This genus and species with illustrations will be treated in the work of Bengtsson (in prep.). 

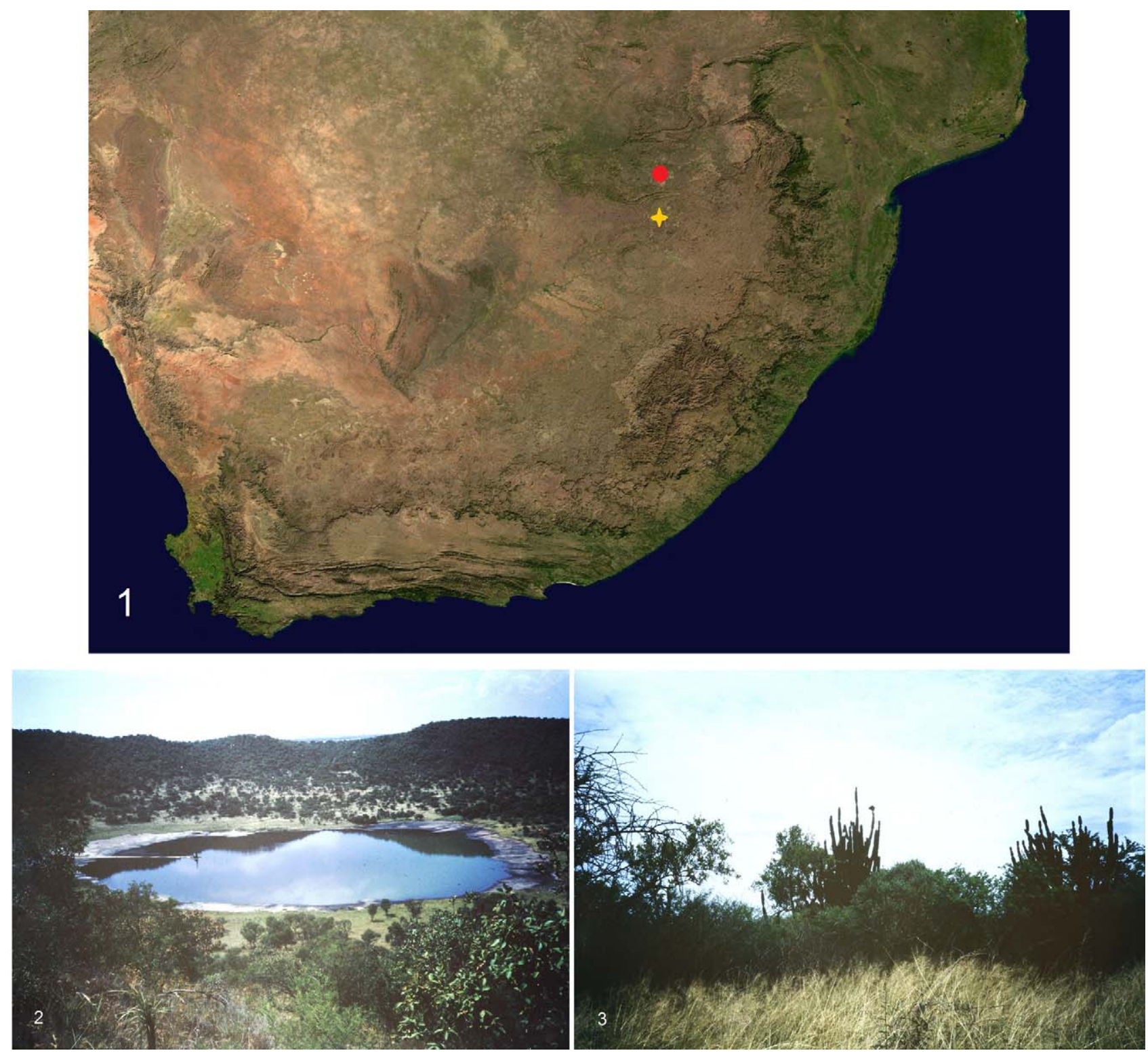

FIGURES 1-3. Locality of the new Urodeta species in South Africa. 1, map, circle-Tswaing Crater Reserve, cross-Pretoria city; 2, general view of Tswaing Crater, photographed by JDP on 15.ii.2002; 3, the collecting site of Urodeta acinacella, sp. nov. and U. quadrifida, sp. nov., photographed by JDP on 16.ii.2002.

\section{Methods}

Sampling. In February 2002 and in November 2004 Urodeta specimens were collected in South Africa by the first author using a $12 \mathrm{~V}, 25 \mathrm{~W}$ mercury vapour light placed in front of a white vertical screen at about $1.60 \mathrm{~m}$ above ground level. The electricity was obtained from a car battery in two different sampling sites: $25^{\circ} 24^{\prime} \mathrm{S} 28^{\circ} 05^{\prime} \mathrm{E}$ and $26^{\circ} 28^{\prime} \mathrm{S} 23^{\circ} 46^{\prime} \mathrm{E}$. The specimens were spread in the usual way in the field and dry preserved for their further study (Lopez-Vaamonde et al. 2012).

Biotope. The sampling habitat (Figs 1-3) is a 220000 year old crater created by a meteorite of up to 30-50 meters in diameter (Koeberl et al. 1994) in the crystalline basement of the 2.05 Ga old Nebo granite of the Bushveld Complex (Walraven et al. 1990). The Tswaing crater lies in the centre of the Tswaing Nature Reserve, South Africa with an elevated circular rim roughly 60 meters above the surrounding bushland. On its floor is a brine lake (Fig. 2). Formerly the lake was the site of a commercial salt-making industry. About $3 \mathrm{~km}$ south-southeast of the Tswaing crater a circular depression with a diameter of about $400 \mathrm{~m}$ is present. The crater depression resulted in a unique ecosystem, primarily caused by changes in the drainage, water 
availability, and in the altered lithology (Cockell et al. 2001). Recent studies (Oberholster et al. 2009) revealed that the restricted species composition of the fauna and flora of the Tswaing Lake displays differences from the fauna and flora recorded for the other alkaline lakes of East Africa. The ecosystems of the Tswaing meteorite crater lake are unique, because the biological diversity and community structure are governed primarily by salinity and the degree of environmental stability (Verschuren et al. 1999). Lake Tswaing receives a very variable annual rainfall which in some years might be above the average regional annual rainfall (Oberholster et al. 2009).

Morphological analysis. Adult specimens were examined externally using Leica MZ12.5 and BMS-10 stereomicroscopes. The forewing length was measured along the costa from wing base to the apex of the terminal fringe scales.

Genitalia were prepared following the method described by Robinson (1976) and Traugott-Olsen \& Schmidt Nielsen (1977). The genitalia were studied and some morphological structures were photographed in glycerol before permanent slide-mounting in Euparal. The male genital capsule was stained with fuchsin and the abdominal pelt and female genitalia with Chlorazol Black (Direct Black 38/Azo Black). The genital morphology was examined using a Biolam AU-12 and Leica DM 2500 microscopes. The descriptive terminology of morphological structures follows Traugott-Olsen \& Schmidt Nielsen (1977), Kaila (1999, 2011), and Kristensen (2003).

The species are arranged alphabetically. Institutional abbreviation used in the text is as follows:

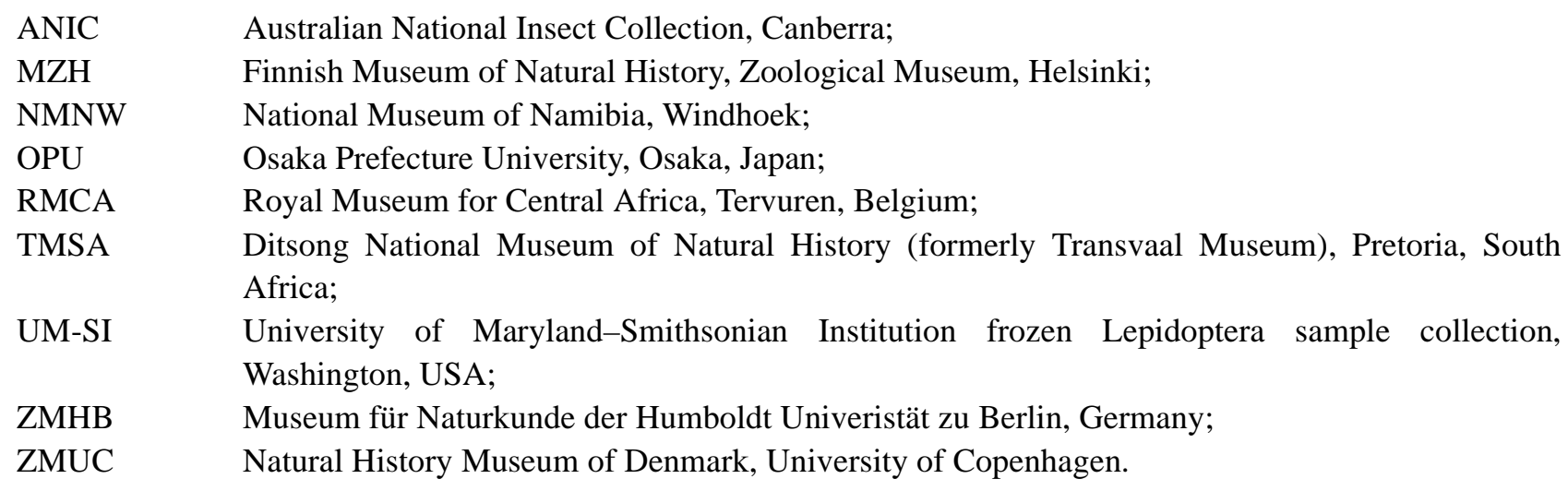

\section{Taxonomy}

Beside the type species $U$. hibernella (Staudinger, 1859) (=U. cisticolella Stainton, 1869) it took almost one and a half century until more species of this formerly monotypic genus were discovered (Kaila 2011, Sruoga \& De Prins 2011). In the monograph on the Australian Elachistinae Kaila (2011) transferred six Afrotropical species which were previously assigned to Phthinostoma Meyrick, 1914b by Mey (2007) and Perittia Stainton, 1854 by Sruoga \& De Prins (2009), to Urodeta. As the consequence of recent publications (Mey 2007; Sruoga \& De Prins 2009, 2011; Kaila 2011) Urodeta became the second species-rich genus of Elachistinae in the Afrotropics, after Elachista. In this paper, we describe three additional new species of Urodeta which were discovered in South Africa. 

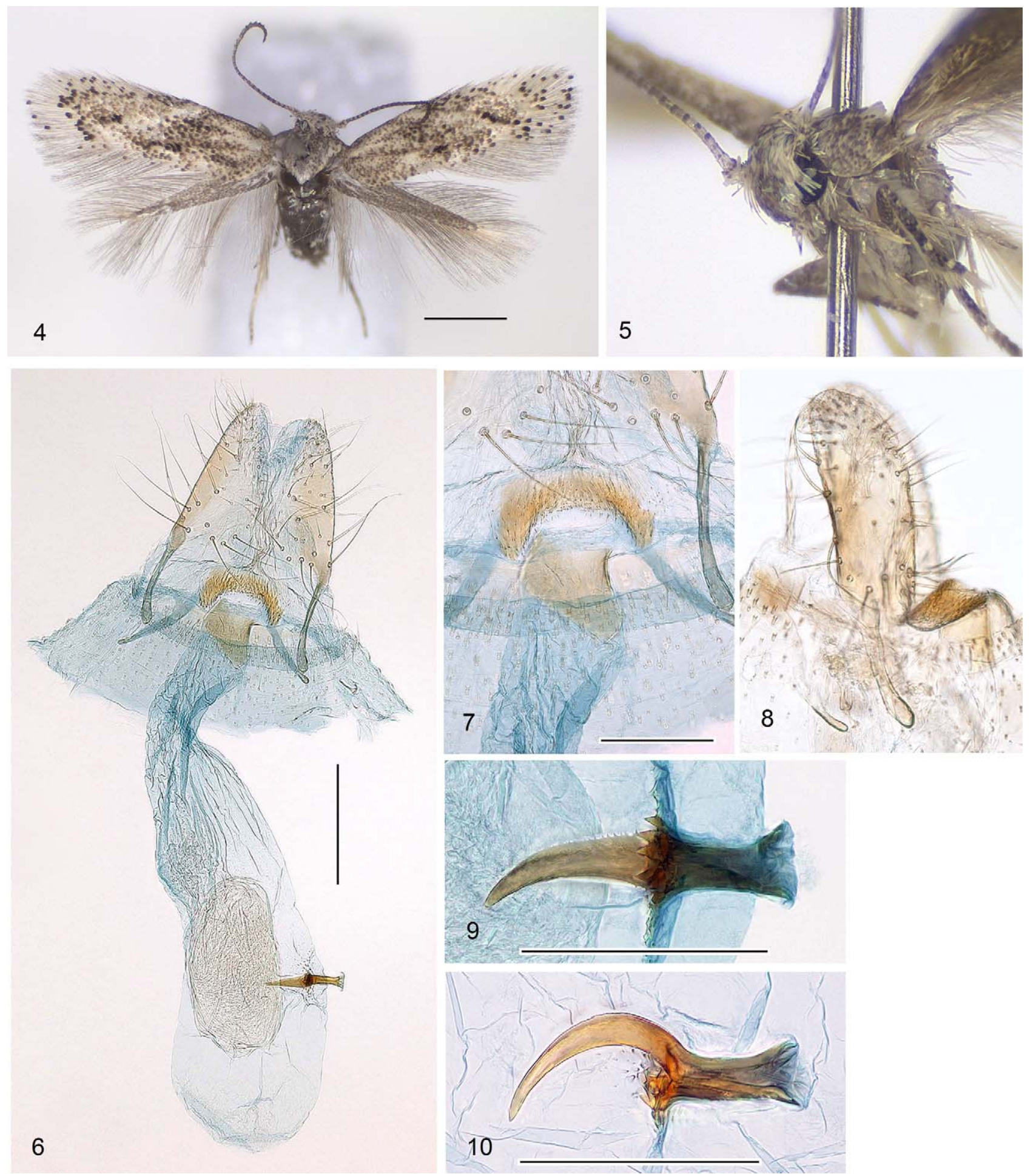

FIGURES 4-10. Urodeta acinacella, sp. nov. 4-7, holotype female. Gen. prep. MRAC/KMMA 00661; specimen ID: RMCA ENT 000006119. 4, adult female. Scale bar $1 \mathrm{~mm} ; 5$, head, latero-frontal view, female; 6 , female genitalia. Scale bar $0.2 \mathrm{~mm} ; 7$, ostium region. Scale bar $0.1 \mathrm{~mm}$; 8-10, paratypes; specimen IDs: RMCA ENT 000006118, 000006121. 8, caudal part of genitalia, lateral view. In glycerol before permanent mounting in Euparal. Paratype female. Gen. prep. MRAC/KMMA 00663; specimen ID: RMCA ENT 000006121; 9, signum. Paratype female. Gen. prep. MRAC/KMMA 00662; specimen ID: RMCA ENT 000006118. Scale bar $0.1 \mathrm{~mm}$; 10, signum. Paratype female. Gen. prep. MRAC/KMMA 00663; specimen ID: RMCA ENT 000006121. Scale bar $0.1 \mathrm{~mm}$. 


\section{Descriptions of new species}

\section{Urodeta acinacella Sruoga et De Prins, sp. nov.}

(Figs 4-10)

Type material. Holotype: + , SOUTH AFRICA, Gauteng, $1100 \mathrm{~m}$, Tswaing Crater Reserve, $25^{\circ} 24^{\prime} \mathrm{S} 28^{\circ} 05^{\prime} \mathrm{E}$, 16.xi.2004, leg. J. \& W. De Prins. Specimen ID: RMCA ENT 000006119, gen. prep. MRAC/KMMA 00661 (RMCA).

Paratypes: 2 , , same data as holotype. Specimen IDs: RMCA ENT 000006118, 000006121, gen prep. MRAC/ KMMA 00662, 00663 (RMCA).

Diagnosis. Urodeta acinacella is a small, lightly-coloured species, with indistinct wing markings. In female genitalia, this species is comparable to U. falciferella (Sruoga \& De Prins), known from Kenya (for external characters and female genitalia refer to Sruoga \& De Prins 2009). However, the forewing in the new species is narrower and more lightly-coloured, the dorsal wall of antrum is semicircular and distally directed, the ductus bursae with longitudinal folds and without internal spines.

Female (Figs 4, 5). Forewing length 2.5-3.0 mm; wingspan 5.6-6.5 mm (n=3). Head: Frons, vertex and neck tuft greyish white, mottled with brown tipped scales; labial palpus straight, very short, greyish white, tip blackish brown; scape greyish white, mottled with brown, pecten blackish brown; flagellum greyish brown annulated with paler rings, serrate distally. Thorax and tegulae greyish brown, slightly mottled due to darker tips of scales. Forewing strongly mottled with scales basally whitish and distally from pale brown to blackish brown; blackish brown scales forming spot of raised scales on fold before middle of wing, and other small spot at 2/3 from base of wing. Fringe scales brownish grey with irregularly scattered blackish brown tipped scales. Hindwing brownish grey, its fringe paler.

Male. Unknown.

Female genitalia (Figs 6-10). Papillae anales scerotized, longer than wide, sparsely covered with long setae. Apophyses posteriores apically dilated, length about 0.6 of papillae anales. Tergum 8 very short, apophyses anteriores markedly more slender than apophyses posteriores in apical part (Figs 6,8), very weakly sclerotized, extending from central part of segment and spreading apart laterad. Dorsal wall of antrum is semicircular, strongly sclerotized and distally directed, covered by small spines (Fig. 8). Colliculum sclerotized, about 1/2 length of apophyses posteriores. Ductus bursae with longitudinal folds and small internal spines, gradually broadened cephalically, almost smoothly continued to corpus bursae. Corpus bursae oval, without internal spines; signum elongate, sickle-shaped, with transverse, weakly sclerotized plate covered by tiny spines (Figs 9, 10).

Biology. Unknown.

Flight period. Based upon the specimens available, adults fly in November.

Distribution. So far this species is known only from the Tswaing Nature Reserve in the Gauteng Province of South Africa (Figs 1-3).

Etymology. The species name is derived from the Latin acinaces (short sword, short saber, scimitar) in reference to the shape of the signum.

\section{Urodeta quadrifida Sruoga et De Prins, sp. nov.}

(Figs 11-16)

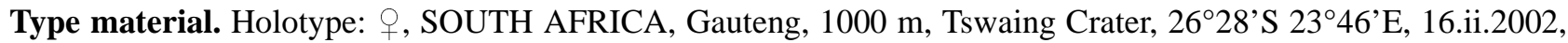
leg. J. \& W. De Prins. Specimen ID: RMCA ENT 000006373, gen. prep. MRAC/KMMA 00626 (RMCA).

Diagnosis. Urodeta quadrifida is a small, lightly-coloured species, with indistinct wing markings. The female genitalia are highly distinctive with four spined spots in ostium bursae region and developed lamella antevaginalis. As such, $U$. quadrifida cannot be confused with any other known species of Urodeta.

Female (Figs 11, 12). Forewing length $3.0 \mathrm{~mm}$; wingspan $6.8 \mathrm{~mm}(\mathrm{n}=1)$. Head: Frons, vertex and neck tuft greyish white, mottled with dark brown tipped scales; labial palpus straight, very short, brown; antenna dark brown, basally annulated with darker rings, serrate distally. Thorax greyish brown, tegulae dark brown, posterior margin of thorax and tegulae greyish white. Forewing strongly mottled with scales basally greyish white and 
distally from pale brown to blackish brown. Fringe scales brownish grey with irregularly scattered brownish black tipped scales. Hindwing brownish grey, its fringe paler.
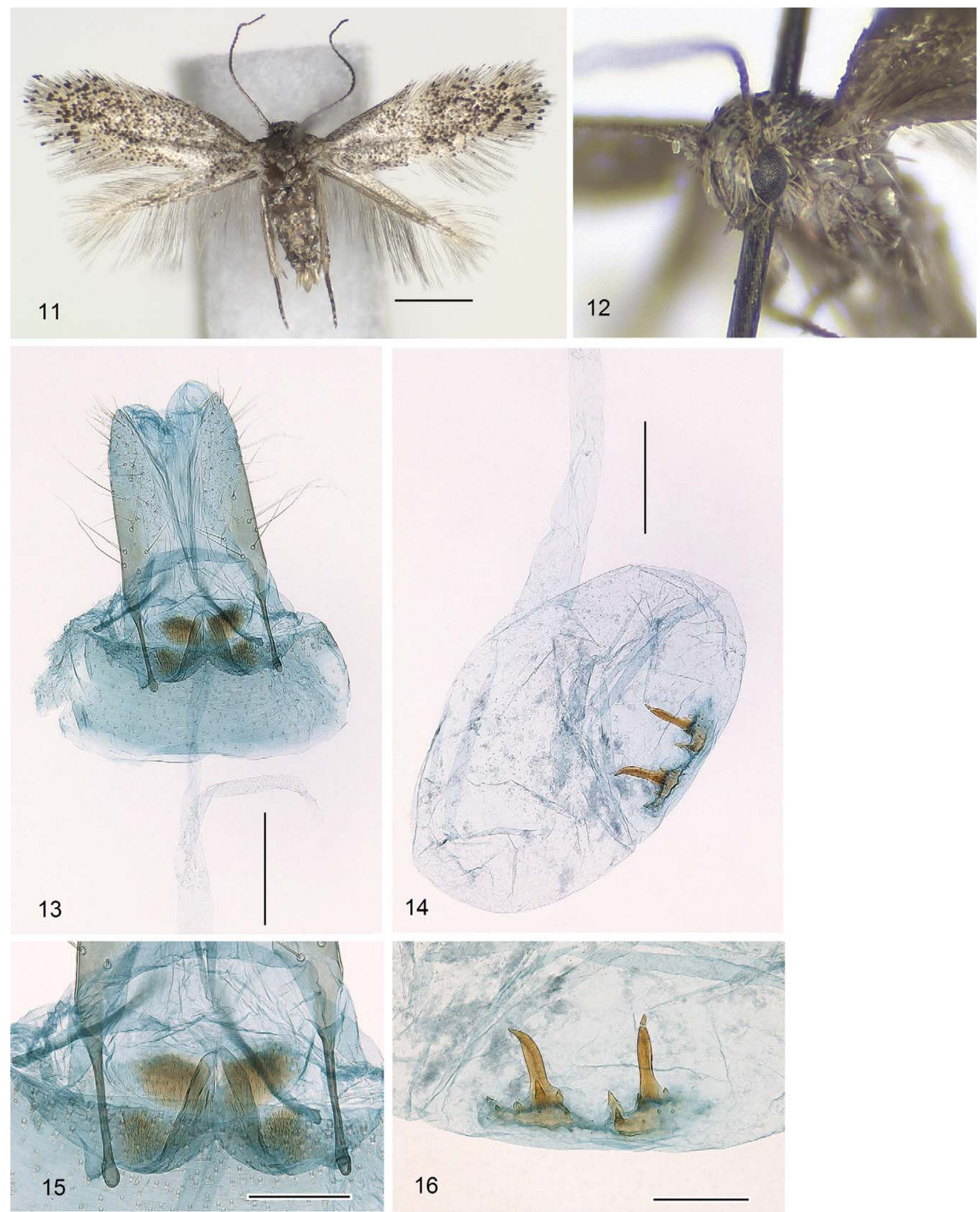

FIGURES 11-16. Urodeta quadrifida, sp. nov., holotype female. Gen. prep. MRAC/KMMA 00626; specimen ID: RMCA ENT 000006373. 11, adult female. Scale bar $1 \mathrm{~mm}$; 12, head, latero-frontal view, female; 13, caudal part of female genitalia; Scale bar $0.2 \mathrm{~mm}$; 14, ductus and corpus bursae. Scale bar $0.2 \mathrm{~mm} ; 15$, ostium region. Scale bar $0.1 \mathrm{~mm}$; 16, signum. Scale bar $0.1 \mathrm{~mm}$. 

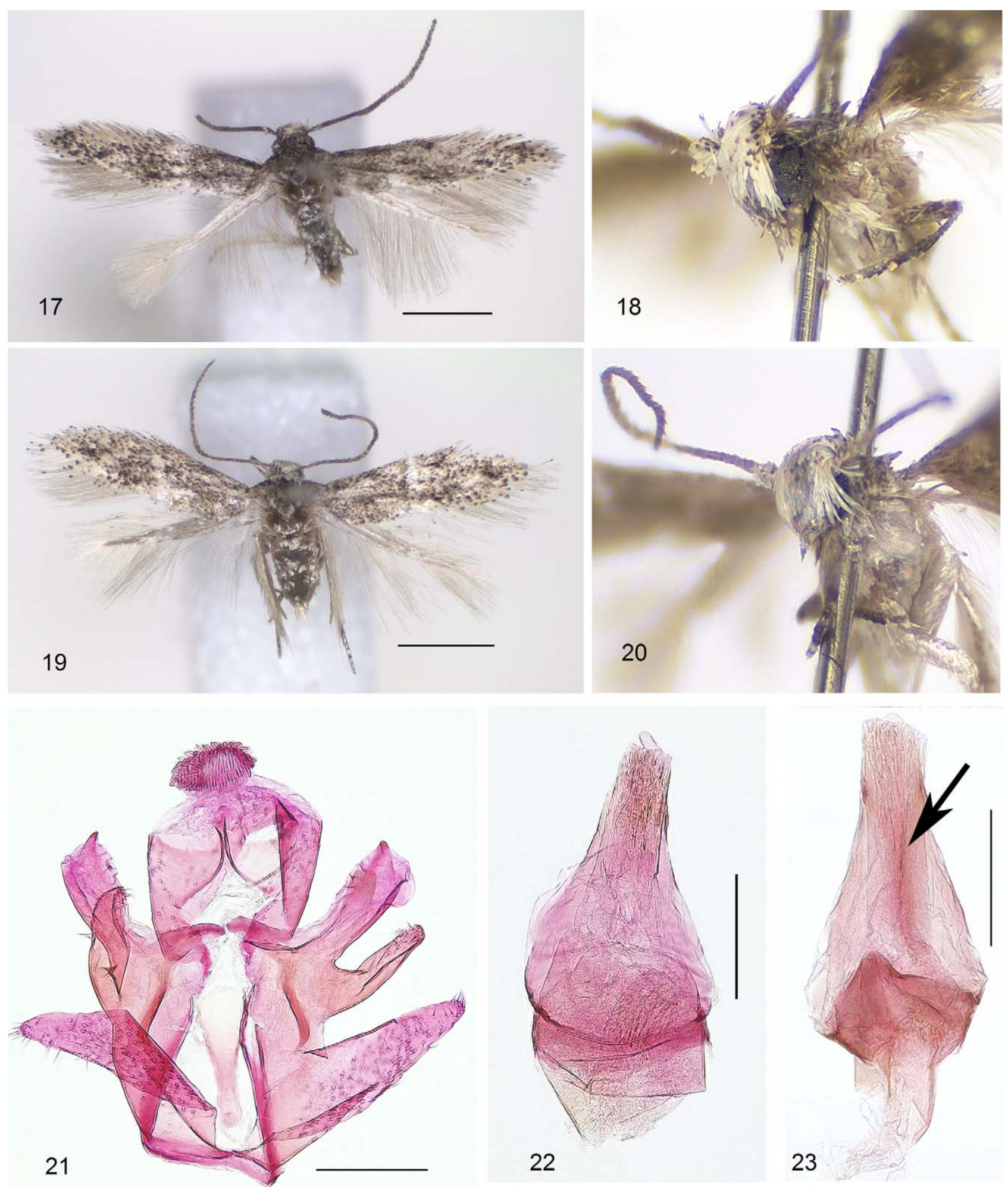

FIGURES 17-23. Urodeta trilobata, sp. nov. 17-18, holotype male, specimen ID: RMCA ENT 000006120. 17, adult male. Scale bar $1 \mathrm{~mm}$; 18, head, latero-frontal view, male; 19-20, paratype female, specimen ID: RMCA ENT 000006122. 19, adult female. Scale bar $1 \mathrm{~mm}$; 20, head, latero-frontal view, female; 21-22, male genitalia. Holotype. Gen. prep. MRAC/KMMA 00664, specimen ID: RMCA ENT 000006120; 21, general view of male genitalia (phallus removed). Scale bar $0.1 \mathrm{~mm}$; 22 , phallus. Scale bar $0.1 \mathrm{~mm}$. 23, phallus and juxta (arrow pointing to ventral shield of juxta). Paratype. Gen. prep. MRAC/ KMMA 00665, specimen ID: RMCA ENT 000006123. Scale bar $0.1 \mathrm{~mm}$.

Male. Unknown.

Female genitalia (Figs 13-16). Papillae anales scerotized, longer than wide, sparsely covered with long setae. 
Apophyses posteriores apically dilated, length about 0.5 of papillae anales. Tergum 8 very short, apophyses anteriores as long as apophyses posteriores, extending from central part of segment and spreading apart laterad. Caudal margin of sternum 7 mesially expanded and bent, forming triangularly-shaped and distally incised lamella antevaginalis behind which situated ostium bursae and four spinose spots. Antrum and colliculum not distinct. Ductus bursae weakly broadened cephalically. Corpus bursae oval, with very small internal spines; signum formed from two connected plates, each with one large spine and few smaller ones.

Biology. Unknown.

Flight period. Based upon the single specimen available, adults fly in February.

Distribution. So far this species is known only from the Tswaing Nature Reserve in the Gauteng Province of South Africa (Figs 1-3).

Etymology. The species name is derived from the Latin quadrifida (four-divided, split into four) in reference to the four spinose spots in female genitalia.

\section{Urodeta trilobata Sruoga et De Prins, sp. nov.}

(Figs 17-28)

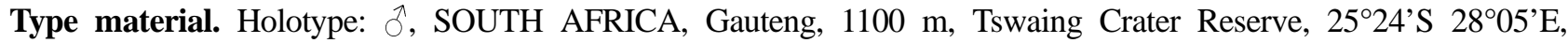
16.xi.2004, leg. J. \& W. De Prins. Specimen ID: RMCA ENT 000006120, gen. prep. MRAC/KMMA 00664 (RMCA).

Paratypes: $1{ }^{\lambda}, 1+$, same data as holotype. Specimen IDs: RMCA ENT 000006123, 000006122, gen. prep. MRAC/KMMA 00665, 00666 (RMCA).

Diagnosis. Urodeta trilobata is a small, lightly-coloured species, with indistinct wing markings. The hindwings of the new species are very narrow and will separate it from all other similarly looking Urodeta species. The trilobed valva in male genitalia, and pair of sclerotized rods laterad from the ostium bursae in female genitalia are very distinctive and separate $U$. trilobata from all other Urodeta species.

Male (Figs 17, 18). Forewing length 2.6-2.7 mm; wingspan 5.9-6.0 mm (n=2). Head: Frons, vertex and neck tuft whitish, mottled with brown-tipped scales; labial palpus straight, very short, blackish brown; scape whitish, mottled with brown; flagellum rather broad, unicolourous, greyish brown. Thorax and tegulae grey-brown, slightly mottled due to darker tips of scales; posterior margin of thorax and tegulae whitish grey. Forewing strongly mottled with scales basally whitish and distally from pale brown to blackish brown; blackish brown scales forming spot on fold before middle of wing, and other small spot at $2 / 3$ from base of wing. Fringe scales brownish grey with irregularly scattered blackish brown tipped scales. Hindwing very narrow, brownish grey, its fringe paler.

Female (Figs 19, 20). Forewing length $2.5 \mathrm{~mm}$; wingspan $5.8 \mathrm{~mm}(\mathrm{n}=1)$. Similar to male, but flagellum narrower and paler, and forewing somewhat broader.

Male genitalia (Figs 21-23). Tegumen short, uncus indeterminate. Basal arms of gnathos long and strongly sclerotized, apically fused to each other; spinose knob of gnathos large, rounded. Valva short and wide, sacculus separated from remaining valva as triangular shaped and weakly sclerotized lobe; termen of valva very deeply emarginated so valva appears divided into long and narrow lobes. Transtilla wide, strongly sclerotized. Ventral shield of juxta elongate and narrow, gradually widened distally, apex rounded and fused to phallus. Vinculum Ushaped, narrow, strongly sclerotized, without saccus. Phallus as long as sacculus, strongly dilated basally, and tapered distally; vesica with two groups of spines: basal group with small prolonged spines, apical group contains very small spines and large ones with rounded tips (Fig. 22) near the apex of phallus.

Female genitalia (Figs 24-28). Papillae anales very short, with scattered long setae; basal margin with very long setae in ventral and dorsal parts; apophyses posteriores vestigial, visible only as very short extension basolaterally (Fig. 28). Segment 8 short, not sclerotized, apophyses anteriores absent. Ostium bursae situated in membrane between sterna 7 and 8, laterally with pair of strongly sclerotized rods. Antrum membranous, slightly shorter than papillae anales. Ductus bursae gradually widening cephalically, almost smoothly continued to corpus bursae, with longitudinal folds and transversal band of small internal spines just before entering to corpus bursae. Corpus bursae oval, with small internal spines, arranged in rows of 3-8 ones (Fig. 26); signum irregular oval sclerotized plate, with one large and several small spines. 

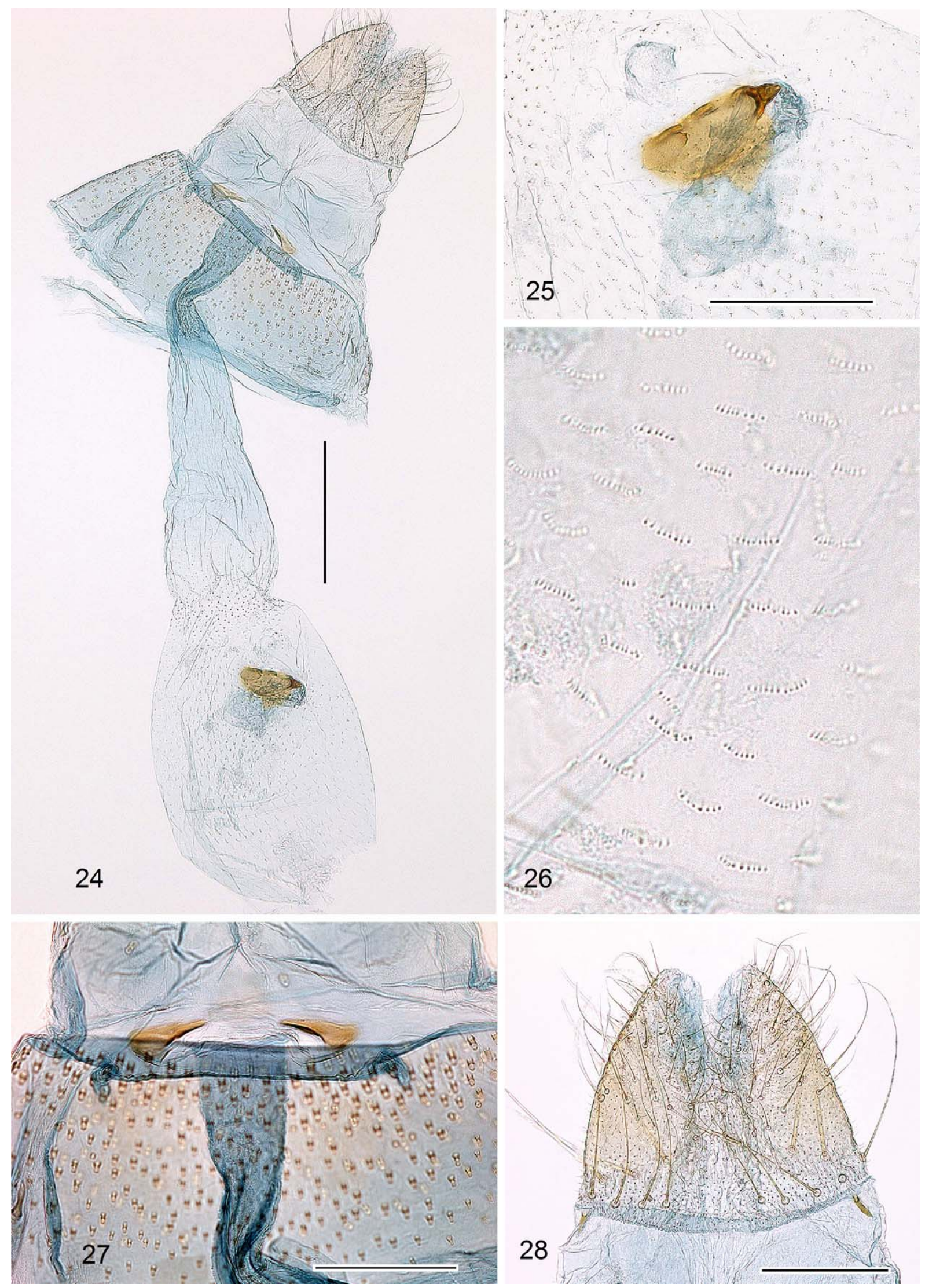

FIGURES 24-28. Urodeta trilobata, sp. nov., female genitalia. Paratype. Gen. prep. MRAC/KMMA 00666, specimen ID: RMCA ENT 000006122. 24, female genitalia. Scale bar $0.2 \mathrm{~mm}$; 25, signum. Scale bar $0.1 \mathrm{~mm}$; 26, spines of corpus bursae; 27 , ostium region. Scale bar $0.1 \mathrm{~mm} ; 28$, papillae anales. Scale bar $0.1 \mathrm{~mm}$. 
Biology. Unknown.

Flight period. Based upon the specimens available, adults fly in November.

Distribution. So far this species is known only from the Tswaing Nature Reserve in the Gauteng Province of South Africa (Figs 1, 2).

Etymology. The species name is derived from Latin tri- (three) and lobate (having lobes), in reference to the shape of the valva.

Remarks. The forewings of type specimens are somewhat rubbed and therefore, the description is approximate.

\section{An annotated checklist of the species of Urodeta Stainton, 1869 of the world}

Urodeta-Stainton, H. T. 1869. The Tineina of Southern Europe: [viii] Errata "226, 13 from bottom, for Urodela read Urodeta." In the combined descriptions of the genus and species on p. 226 the generic name was spelt as Urodela, an incorrect original spelling that was corrected in the Errata printed at the beginning of the work on $\mathrm{p}$. [viii] (Nye \& Fletcher 1991: 318).

Type species: Urodeta cisticolella Stainton, 1869 by monotypy. The type species $U$. cisticolella Stainton, 1869 was synonymized with Butalis hibernella Staudinger, 1859 by Bengtsson (1997: 208).

\section{Urodeta absidata Sruoga \& De Prins, 2011}

“Urodeta absidata, sp. n.”-Sruoga, V. \& De Prins, J. 2011. Zootaxa 3008: 4-5, figs 1, 3, 4, 13-22.

Type locality: Cameroon, North Province, Faro River Camp, 08²3'N 012 $49^{\prime} \mathrm{E}, 275 \mathrm{~m}$.

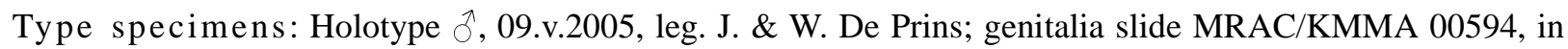
RMCA; Paratype 1q, same locality data as holotype, 02.xii.2003, leg. J. De Prins; genitalia slide MRAC/KMMA 00595, in RMCA.

Host plant(s): Unknown.

Distribution: Cameroon (Sruoga \& De Prins 2011: 5).

\section{Urodeta acerba Sruoga \& De Prins, 2011}

“Urodeta acerba, sp. n.”-Sruoga, V. \& De Prins, J. 2011. Zootaxa 3008: 5-6, figs 2, 3, 5, 23-32.

Type locality: Democratic Republic of the Congo, Bas-Congo, Nature Reserve Luki-Mayumbe, $05^{\circ} 27^{\prime} \mathrm{S}$ $13^{\circ} 05^{\prime} \mathrm{E}, 320 \mathrm{~m}$.

Type specimens: Holotype $\widehat{0}$, 29.iii.2006, leg. J. De Prins; genitalia slide MRAC/KMMA 00596, in RMCA; Paratypes 3 $\hat{\jmath}, 2$, same locality data as holotype, 15.iii.2006, 22.iii.2006, 16.v.2007, leg. J. \& W. De Prins; genitalia slides MRAC/KMMA 00597-00600, in RMCA. DNA voucher AK-07-049, stored in the molecular collection at UM-SI.

Host plant(s): Unknown.

Distribution: the Democratic Republic of the Congo (Sruoga \& De Prins 2011: 6).

\section{Urodeta acinacella Sruoga et De Prins, sp. nov.}

"Urodeta acinacella, sp. nov."- present publication, figs 4-10.

Type locality: South Africa, Gauteng, Tswaing Crater Reserve, $25^{\circ} 24^{\prime} \mathrm{S} 28^{\circ} 05^{\prime} \mathrm{E}, 1100 \mathrm{~m}$.

Type specimens: Holotype ${ }^{+}, 16 . x i .2004$, leg. J. \& W. De Prins; genitalia slide MRAC/KMMA 00661, in RMCA; Paratypes 2 \%, same data as holotype; genitalia slide 00662, 00663, in RMCA.

Host plant(s): Unknown.

Distribution: South Africa (present publication).

\section{Urodeta aculeata Sruoga \& De Prins, 2011}

“Urodeta aculeata, sp. n.”-Sruoga, V. \& De Prins, J. 2011. Zootaxa 3008: 6, figs 1, 3, 4, 33-36.

Type locality: Cameroon, North Province, Faro River Camp, 08 $25^{\prime} \mathrm{N} 012^{\circ} 47^{\prime} \mathrm{E}, 275 \mathrm{~m}$.

Type specimens: Holotype ${ }^{\lambda}$, 04.v.2005, leg. J. \& W. De Prins; genitalia slide MRAC/KMMA 00601, in RMCA. 
Host plant(s): Unknown.

Distribution: Cameroon (Sruoga \& De Prins 2011: 6).

\section{Urodeta bucera Sruoga \& De Prins, 2011}

“Urodeta bucera, sp. n.”-Sruoga, V. \& De Prins, J. 2011. Zootaxa 3008: 6-7, figs 2, 3, 5, 37-49.

Type locality: Democratic Republic of the Congo, Bas-Congo, Nature Reserve Luki-Mayumbe, $05^{\circ} 27^{\prime S}$ $13^{\circ} 15^{\prime} \mathrm{E}, 320 \mathrm{~m}$.

Type specimens: Holotype $\widehat{~}$, 15.iii.2006, leg. J. \& W. De Prins; genitalia slide MRAC/KMMA 00602, in

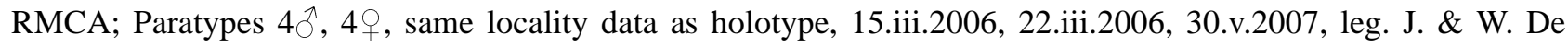
Prins; genitalia slides MRAC/KMMA 00603-00609, in RMCA.

Host plant(s): Unknown.

Distribution: the Democratic Republic of the Congo (Sruoga \& De Prins 2011: 7).

\section{Urodeta crenata Sruoga \& De Prins, 2011}

“Urodeta crenata, sp. n.”-Sruoga, V. \& De Prins, J. 2011. Zootaxa 3008: 7-8, figs 1, 3, 4, 50-55.

Type locality: Cameroon, North Province, Faro River Camp, 08²3'N 012 $49^{\prime} \mathrm{E}, 275 \mathrm{~m}$.

Type specimens: Holotype $\widehat{\jmath}$, 01.v.2005, leg. J. \& W. De Prins; genitalia slide MRAC/KMMA 00610, in RMCA; Paratype 10 , same locality data as holotype, 09.v.2005, leg. J. \& W. De Prins; genitalia slide MRAC/ KMMA 00611, in RMCA.

Host plant(s): Unknown.

Distribution: Cameroon (Sruoga \& De Prins 2011: 8).

\section{Urodeta cuspidis Sruoga \& De Prins, 2011}

“Urodeta cuspidis, sp. n.”-Sruoga, V. \& De Prins, J. 2011. Zootaxa 3008: 8-9, figs 1, 3, 4, 56-63.

Type locality: Cameroon, North Province, Faro River Camp, 08²5'N 012²7'E, $275 \mathrm{~m}$.

Type specimens: Holotype $\widehat{\text { O }}$, 04.v.2005, leg. J. \& W. De Prins; genitalia slide MRAC/KMMA 00612, in RMCA; Paratypes $3 \hat{\jmath}$, same locality data as holotype, 01.v.2005, 04.v.2005, 09.v.2005, leg. J. \& W. De Prins; genitalia slides MRAC/KMMA 00613-00615, in RMCA.

Host plant(s): Unknown.

Distribution: Cameroon (Sruoga \& De Prins 2011: 9).

\section{Urodeta falciferella (Sruoga \& De Prins, 2009)}

"Perittia falciferella, new species"-Sruoga, V. \& De Prins, J. 2009. Zootaxa 2172: 14, figs 4, 15, 33, 41-43. Transferred to Urodeta by Kaila \& Sugisima (2011: 16).

Type locality: Kenya, Kakamega Forest, $00^{\circ} 21^{\prime} \mathrm{N} 034^{\circ} 51^{\prime} \mathrm{E}, 1590 \mathrm{~m}$.

Type specimens: Holotype 9 , mine 28.iii.2003, ex p. 21.iv.2003, leg. J. \& W. De Prins; genitalia slide MRAC/KMMA 00477, in RMCA; Paratypes 2 , same locality data as holotype, mine 28.iii.2003, ex. p. 21.iv.2003, leg. J. \& W. De Prins; genitalia slide MRAC/KMMA 00478, in RMCA.

Host plant (s): Unknown: unidentified plant.

Distribution: Kenya (Sruoga \& De Prins 2009: 14).

\section{Urodeta faro Sruoga \& De Prins, 2011}

“Urodeta faro, sp. n."-Sruoga, V. \& De Prins, J. 2011. Zootaxa 3008: 9, figs 1, 3, 4, 64-71.

Type locality: Cameroon, North Province, Faro River Camp, 08²3'N 01249'E, $275 \mathrm{~m}$.

Type specimens: Holotype , 09.v.2005, leg. J. \& W. De Prins; genitalia slide MRAC/KMMA 00622, in RMCA; Paratypes 2 , same locality data as holotype, 04.v.2005, leg. J. \& W. De Prins; 28.iv-09.v.2005, leg. K. Larsen \& T. Zandersen; genitalia slides MRAC/KMMA 00623, 00644, in RMCA.

Host plant(s): Unknown.

Distribution: Cameroon (Sruoga \& De Prins 2011: 9).

Urodeta gnoma (Sruoga \& De Prins, 2009)

“Perittia gnoma, new species"-Sruoga, V. \& De Prins, J. 2009. Zootaxa 2172: 15-17, figs 1, 15, 32, 37-40. 
Transferred to Urodeta by Kaila \& Sugisima (2011: 16).

Type locality: Kenya, Arabuko Sokoke Forest, $20 \mathrm{~km} \mathrm{~W}$ Gede, $03^{\circ} 25^{\prime} \mathrm{S} 039^{\circ} 53^{\prime} \mathrm{E}, 90 \mathrm{~m}$.

Type specimens: Holotype $\widehat{\partial}$, 31.iii.2004, leg. J. De Prins; genitalia slide MRAC/KMMA 00473, in RMCA; Paratypes 2へ, same locality data as holotype, 21.iv.2002, 25.iii.2004, leg. J. De Prins, leg. J. \& W. De Prins; genitalia slides MRAC/KMMA 00474, 00475, in RMCA.

Host plant(s): Unknown.

Distribution: Kenya (Sruoga \& De Prins 2009: 17).

\section{Urodeta hibernella (Staudinger, 1859)}

"112. Butalis Hibernella"-Staudinger, O. 1859. Entomologische Zeitung [Entomologischer Verein zu Stettin]: 250. Transferred to Urodeta by Bengtsson (1997: 208).

“Urodela, n. g., cisticolella, n. sp."-Stainton, H.T. 1869. The Tineina of Southern Europe: 226-227. A junior subjective synonym of Butalis hibernella Staudinger 1859, synonymized by Bengtsson (1997: 208).

Type locality: Spain, Andalusia, Chiclana.

Type specimens: Holotype ${ }^{\Uparrow}$ [without abdomen], 26.ii.1857 or 1858, leg. O. Staudinger, in ZMHB.

Host plant(s): Cistus monspeliensis L. (Stainton 1869: 227), C. salviaefolius L (Lhomme 1946-1963: 869), Cistus $\times$ ledon Lam. and C. ladaniferus Stokes (Zerkowitz, 1946: 125) (Cistaceae).

Distribution: Algeria (Rebel 1901: 206), Corsica (Riedl 1996: 95), France (Stainton 1869: 226), Monaco (Lhomme 1946-1963: 869), Morocco, Tunisia (Rebel 1901: 206), Portugal (Zerkowitz 1946: 125), Spain (Staudinger 1859: 250).

\section{Urodeta inusta Kaila, 2011}

“Urodeta inusta, sp. n."-Kaila, L. 2011. Monographs on Australian Lepidoptera 11: 45-46, pl.1: figs 1, 2; figs 11, 23, 36, 95, 96, 98 .

Type locality: Australia, Western Australia, $163 \mathrm{~km}$ SE by E Broome, $18^{\circ} 49^{\prime} \mathrm{S} 123^{\circ} 17^{\prime} \mathrm{E}$.

Type specimens: Holotype $\widehat{\jmath}$, 04.viii.1976, leg. I.F.B. Common; genitalia slide ANIC 15758, in ANIC; Paratypes $2{ }^{\lambda}, 1$, , same locality data as holotype, 03.viii.1976, $101 \mathrm{~km}$ SE by E Broome, 19.viii.1976; leg. I.F.B. Common; genitalia slides ANIC 17329, 17330, in ANIC; LK 5140, in MZH.

Host plant(s): Unknown.

Distribution: Australia (Kaila 2011: 46).

\section{Urodeta maculata (Mey, 2007)}

"Phthinostoma maculata, spec. nov."-Mey, W. 2007. Esperiana Memoir 4: 21-22, figs 30-34, pl. 1: fig. 7. Transferred to Urodeta by Kaila \& Sugisima (2011: 16).

Type locality: Namibia, Waterberg National Park.

Type specimens: Holotype ${ }^{\lambda}, 12-22 . x i .2000$, leg. W. Mey; genitalia slide Mey 34/07, in ZMHB; Paratypes $17 ð, 26$, same locality data as holotype, Bushmanland, East Caprivi, Halali, Kavango, Kunene, Nanais, near Uis, 18-23.iii.1992, 19-21.ii.1992, 26.ii-03.iii.1992, 22.xi.1993, 16-17.xii.1993, 18.xii.1993, 26-27.xi.2000, 23.iii.2001, 02.iii.2002; leg. W. Mey, leg. W. Mey \& K. Ebert; genitalia slides Mey 26/06, 35/07, 26/07, 37/07, in ZMHB, NMNW.

Host plant(s): Unknown.

Distribution: Namibia (Mey 2007: 21).

Note: Mey (2007: 22) thinks that $U$. maculata "is obviously widely distributed in the savanna Biome of Namibia and may occur also in the neighbouring countries Botswana, Zimbabwe and Angola. It often occurs together with congeneric species". However, there are no published records yet referring to the specimens caught in these three latter countries.

\section{Urodeta quadrifida Sruoga et De Prins, sp. nov.}

"Urodeta quadrifida, sp. nov." - present publication, figs 11-16.

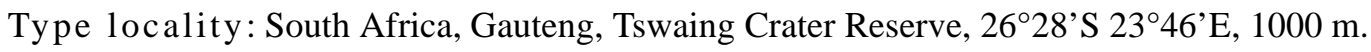

Type specimens: Holotype + , 16.ii.2002, leg. J. \& W. De Prins; genitalia slide MRAC/KMMA 00626, in RMCA. 
Host plant(s): Unknown.

Distribution: South Africa (present publication).

\section{Urodeta spatulata (Sruoga \& De Prins, 2009)}

"Perittia spatulata, new species"-Sruoga, V. \& De Prins, J. 2009. Zootaxa 2172: 17-21, figs 1, 15, 34, 35, 44-49.

Transferred to Urodeta by Kaila \& Sugisima (2011: 16).

Type locality: Kenya, Arabuko Sokoke Forest, $15 \mathrm{~km}$ W Gede, $03^{\circ} 17^{\prime} \mathrm{S} 039^{\circ} 59^{\prime} \mathrm{E}, 50 \mathrm{~m}$.

Type specimens: Holotype $\widehat{ }$, 17.iii.2004, leg. J. \& W. De Prins; genitalia slide MRAC/KMMA 00463, in RMCA; Paratypes 5 $\overbrace{}^{\lambda}$ and 11 , same locality data as holotype, 17.iii.2004, 01.iv.2004, 02.iv.2004, 05.iv.2004, 06.iv.2004, 08.iv.2004, leg. J. De Prins, leg. J. \& W. De Prins; genitalia slides MRAC/KMMA 00464-00472, in RMCA.

Host plant(s): Unknown.

Distribution: Kenya (Sruoga \& De Prins 2009: 21).

\section{Urodeta taeniata (Mey, 2007)}

"Phthinostoma taeniata, spec. nov."-Mey, W. 2007. Esperiana Memoir 4: 22, figs 35-37. Transferred to Urodeta by Kaila \& Sugisima (2011: 16).

Type locality: Namibia, Otavi Mts., Varianto Farm.

Type specimens: Holotype + , 29-31.iii.2001, leg. W. Mey; genitalia slide Mey 39/07, ZMHB; Paratypes 6ㅇ, same locality data as holotype, Nawuarib valley, 1400 m, 02.xii.2000, 29-31.iii.2001; leg. W. Mey; genitalia slides Mey 40/07, 4/06, in ZMHB.

Host plant(s): Unknown.

Distribution: Namibia (Mey 2007: 21).

\section{Urodeta talea Sruoga \& De Prins, 2011}

“Urodeta talea, sp. n.”-Sruoga, V. \& De Prins, J. 2011. Zootaxa 3008: 9-10, figs 2, 3, 5, 72-82.

Type locality: the Democratic Republic of the Congo, Bas-Congo, Nature Reserve Luki-Mayumbe, $05^{\circ} 27^{\prime} \mathrm{S}$ $13^{\circ} 05^{\prime} \mathrm{E}, 320 \mathrm{~m}$.

Type specimens: Holotype $\widehat{\jmath}$, 15.iii.2006, leg. J. \& W. De Prins; genitalia slide MRAC/KMMA 00616, in RMCA; Paratypes 6 $\overbrace{}^{\dagger}$, 9 , same locality data as holotype, 15.iii.2006, 22.iii.2006, 05.iv.2006, 16.v.2007, 23.v.2007, leg. J. \& W. De Prins; genitalia slides MRAC/KMMA 00617-00621, in RMCA. DNA vouchers AK-07075, AK-07-088, stored in the molecular collection at UM-SI.

Host plant(s): Unknown.

Distribution: the Democratic Republic of the Congo (Sruoga \& De Prins 2011: 10).

\section{Urodeta tantilla (Sruoga \& De Prins, 2009)}

"Perittia tantilla, new species"-Sruoga, V. \& De Prins, J. 2009. Zootaxa 2172: 21-23, figs 4, 15, 36, 50, 51. Transferred to Urodeta by Kaila \& Sugisima (2011: 16).

Type locality: Kenya, Kakamega Forest, $00^{\circ} 20^{\prime} \mathrm{N} 034^{\circ} 52^{\prime} \mathrm{E}, 1575 \mathrm{~m}$.

Type specimens: Holotype $\widehat{\partial}$, 01.iv.2003, leg J. \& W. De Prins; genitalia slide MRAC/KMMA 00476, in RMCA.

Host plant(s): Unknown.

Distribution: Kenya (Sruoga \& De Prins 2009: 22).

\section{Urodeta tortuosa Sruoga \& De Prins, 2011}

“Urodeta tortuosa, sp. n.”-Sruoga, V. \& De Prins, J. 2011. Zootaxa 3008: 10-11, figs 1, 3, 4, 83-88.

Ty pe locality: Cameroon, North Province, Faro River Camp, 08²3'N 012 $49^{\prime} \mathrm{E}, 275 \mathrm{~m}$.

Type specimens: Holotype ${ }^{\circ}, 09 . v .2005$, leg. J. \& W. De Prins; genitalia slide MRAC/KMMA 00624, in RMCA.

Host plant(s): Unknown.

Distribution: Cameroon (Sruoga \& De Prins 2011: 11). 


\section{Urodeta trilobata Sruoga et De Prins, sp. nov.}

"Urodeta trilobata, sp. nov."- present publication, figs 17-28.

Type locality: South Africa, Gauteng, Tswaing Crater Reserve, $25^{\circ} 24^{\prime} \mathrm{S} 28^{\circ} 05^{\prime} \mathrm{E}, 1100 \mathrm{~m}$.

Type specimens: Holotype $\widehat{O}$, 16.xi.2004, leg. J. \& W. De Prins; genitalia slide MRAC/KMMA 00664, in

RMCA; Paratypes $1 \hat{0}, 1$, same data as holotype; genitalia slides MRAC/KMMA 00665, 00666, in RMCA.

Host plant(s): Unknown.

Distribution: South Africa (present publication).

\section{Urodeta sp.}

“Urodeta sp."-Kaila, L. 2011. Monographs on Australian Lepidoptera 11: 46-47, figs 97, 99.

Locality: Australia, Queensland, Maryfarms, $30 \mathrm{~km}$ W Mossman.

Specimens: $1{ }^{\lambda}, 1$, , mine 01.iii.1998, ex. 13.iii.1998, 15.iii.1998, leg. K. Sugisima \& T. Kumata; genitalia slides

K. Sugisima 0774, 0775, in OPU.

Host plant(s): Terminalia sp. (Combretaceae)

Distribution: Australia (Kaila 2011: 47)."

\section{Key to the species of Urodeta based on male genitalia*}

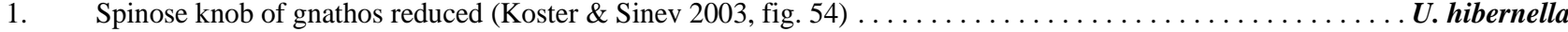
Spinose knob of gnathos well developed, armed with spines directed cephalically $\ldots \ldots \ldots \ldots \ldots \ldots \ldots \ldots \ldots \ldots$

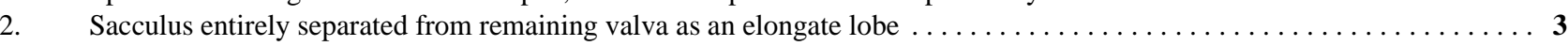

Sacculus not separated from remaining valva $\ldots \ldots \ldots \ldots \ldots \ldots \ldots \ldots \ldots \ldots \ldots \ldots \ldots \ldots \ldots \ldots \ldots \ldots \ldots$

3. Valva divided into two separate lobes (sacculus and remaining part of valva); phallus not dilated basally (Sruoga \& De Prins

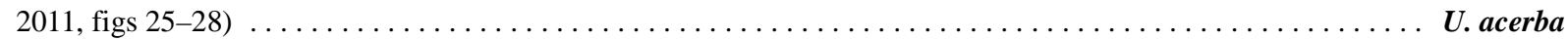
Valva divided into three distinct lobes (sacculus entirely separated and termen of remaining part of valva deeply emarginated so appear divided into long and narrow lobes); phallus strongly dilated basally (figs 22,23$) \ldots \ldots \ldots \ldots$. trilobata

4. Ventral margin of sacculus partly serrated (Sruoga \& De Prins 2011 , figs $52-55) \ldots \ldots \ldots \ldots \ldots \ldots$. . . . . . . . . . . . .

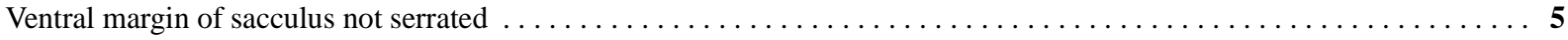

5. Spinose knob of gnathos divided into two separated lobes (Sruoga \& De Prins 2011, figs 39-41) ........ U. bucera

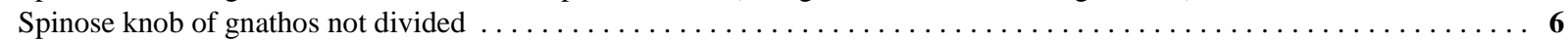

6. Inner processes of valvae fused apically and embedded with many small cusp-shaped spines (Sruoga \& De Prins 2011, figs

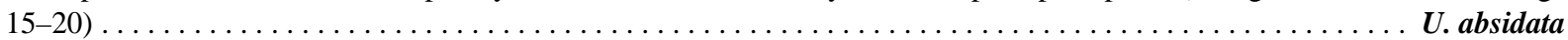

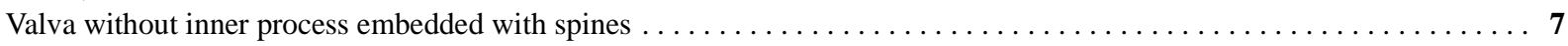

7. Phallus with strongly sclerotized narrow streak along ventral margin $\ldots \ldots \ldots \ldots \ldots \ldots \ldots \ldots \ldots \ldots \ldots \ldots \ldots$ Phallus without strongly sclerotized narrow streak along ventral margin $\ldots \ldots \ldots \ldots \ldots \ldots \ldots \ldots \ldots \ldots \ldots \ldots$

8. Distal margin of juxta deeply indentated, with two distinct, sclerotized lobes (Sruoga \& De Prins 2011, figs 35, 36)

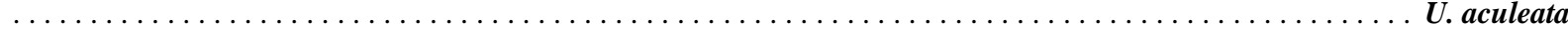

Distal margin of juxta not indentated and without distinct lobes $\ldots \ldots \ldots \ldots \ldots \ldots \ldots \ldots \ldots \ldots \ldots \ldots \ldots \ldots$

9. Valvae are tightly fused together dorso-proximally; vesica with two clusters of large cornuti (12-15 and 12-16) and with several minute spines (Sruoga $\&$ De Prins 2011, figs $74-76) \ldots \ldots \ldots \ldots \ldots \ldots \ldots \ldots \ldots \ldots \ldots \ldots \ldots \ldots \ldots \ldots \ldots$ Valvae not fused together dorso-proximally; vesica with one cluster of 4 large cornuti and with several minute spines (Mey

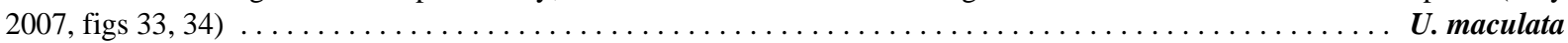

10. Vesica without cornuti (Kaila 2011, fig. 97) $\ldots \ldots \ldots \ldots \ldots \ldots \ldots \ldots \ldots \ldots \ldots \ldots \ldots \ldots \ldots \ldots \ldots \ldots$ sp. reared from Terminalia sp. Vesica with cornuti $\ldots \ldots \ldots \ldots \ldots \ldots \ldots \ldots \ldots \ldots \ldots \ldots \ldots \ldots \ldots \ldots \ldots \ldots \ldots \ldots \ldots \ldots \ldots \ldots \ldots 11$

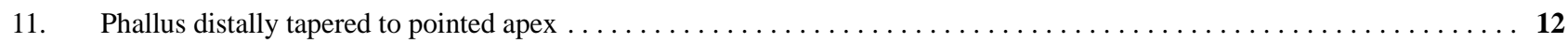

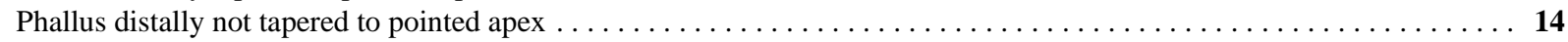

12. Vesica with one large cornuti and with group of minute spines (Sruoga \& De Prins 2011, figs 58-63) ........ U. cuspidis Vesica with more than one large cornuti and can be with group of minute spines $\ldots \ldots \ldots \ldots \ldots \ldots \ldots$

13. Costa shorter than spinose knob of gnathos; spinose knob of gnathos rounded (Kaila 2011, fig. 95) ......... U. inusta Costa at least twice longer than spinose knob of gnathos; spinose knob of gnathos wider than long (Sruoga \& De Prins 2009,

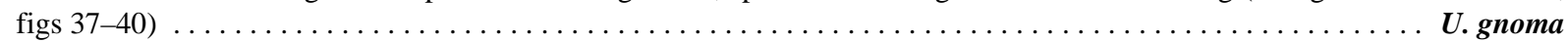

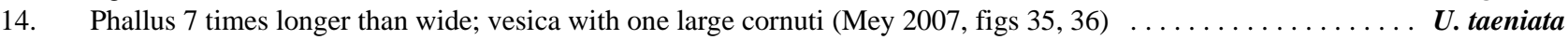
Phallus 4-5 times longer than wide; vesica with few large cornuti and many tiny spines $\ldots \ldots \ldots \ldots \ldots \ldots \ldots \ldots$

15. Ventral shield of juxta with distinct apically rounded lobes; sacculus very short, less than length of spinose knob of gnathos; vesica with 6 large cornuti and numerous tiny spines (Sruoga \& De Prins 2009, figs 50, 51) . . . . . . . . . U. tantilla Ventral shield of juxta without distinct lobes; sacculus long, at least twice longer than length of spinose knob of gnathos; vesica with two rows of large cornuti (4-5 in each row) and numerous tiny spines (Sruoga \& De Prins 2009, figs 44-47)

U. spatulata

* males of U. acinacella, U. falciferella, U. faro, U. quadrifida, and U. tortuosa are unknown. 


\section{Key to the species of Urodeta based on female genitalia*}

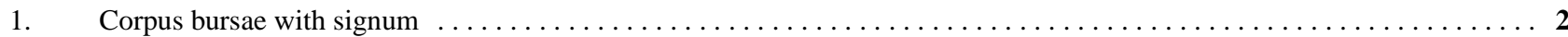

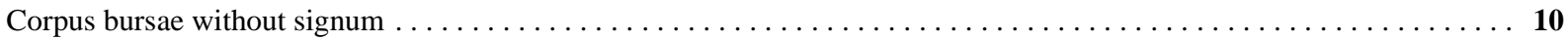

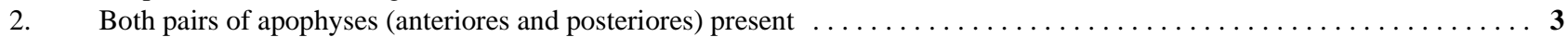

Apophyses anteriores absent $\ldots \ldots \ldots \ldots \ldots \ldots \ldots \ldots \ldots \ldots \ldots \ldots \ldots \ldots \ldots \ldots \ldots \ldots \ldots$

Apophyses posteriores very short, about 4.5 times longer than wide (Sruoga \& De Prins 2011, figs 42-49) ..... U. bucera

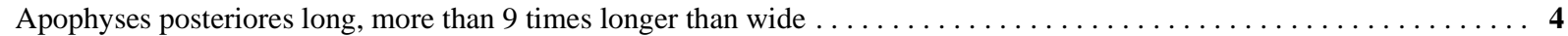

4. Signum formed by weakly sclerotized plate with four large teeth in row (Kaila 2011, fig. 98) $\ldots \ldots \ldots \ldots$. . . inusta

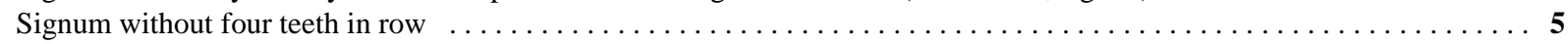

5. Ductus bursae not coiled, gradually broadened cephalically, almost smoothly continued to corpus bursae $\ldots \ldots \ldots \ldots 6$

Ductus bursae coiled or not coiled, much narrower than corpus bursae $\ldots \ldots \ldots \ldots \ldots \ldots \ldots \ldots \ldots \ldots \ldots \ldots \ldots$

6. Dorsal wall of antrum covered by small spines; ductus bursae with longitudinal folds; signum sickle-shaped (figs 6-10) .... .

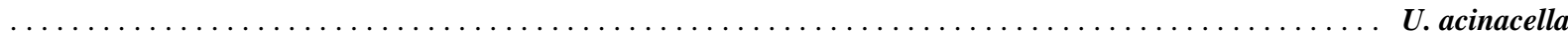

Dorsal wall of antrum without small spines; ductus bursae without longitudinal folds; signum not sickle-shaped (Koster \&

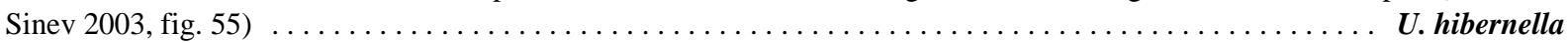

7. Ductus bursae coiled, with internal spines; signum formed by one sickle-shaped spine and weakly sclerotized transverse plate

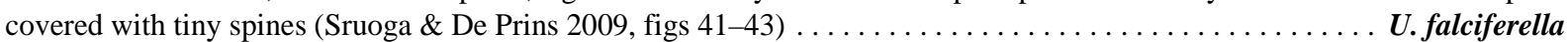
Ductus bursae not coiled, without internal spines; signum formed by two weakly connected plates, each with a large spine and

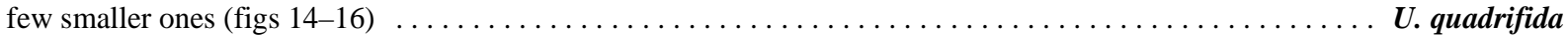

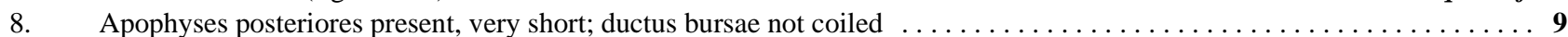
Apophyses absent; ductus bursae coiled (Sruoga \& De Prins 2011, figs 77-82) $\ldots \ldots \ldots \ldots \ldots \ldots \ldots \ldots \ldots$. . . . . . . . .

9. Signum formed by weakly sclerotized plate with four long teeth in row; corpus bursae without internal spines (Mey 2007, figs

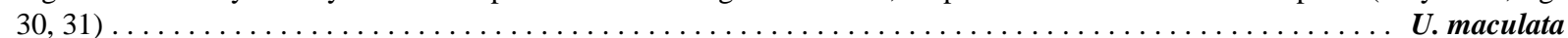
Signum formed by oval sclerotized plate with one large and several small spines; corpus bursae with internal spines, arranged

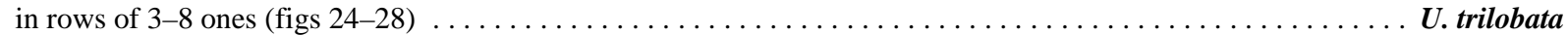

10. Apophyses posteriores vestigial, apophyses anteriores absent (Kaila 2011, fig. 99) . . . . U. Sp. reared from Terminalia sp.

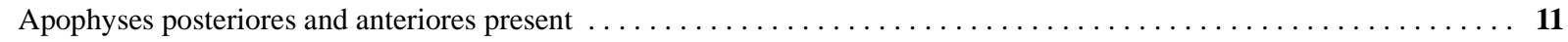

11. Corpus bursae divided by narrow prolonged constriction into two parts (Sruoga \& De Prins 2011, figs 29-32) ... U. acerba

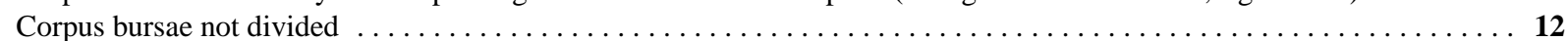

12. Corpus bursae narrow and long, about 4 times longer than wide (Sruoga \& De Prins 2011, figs 21, 22) . .... U.absidata

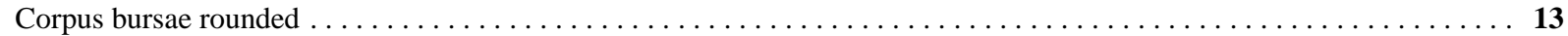

13. Antrum with strongly sclerotized longitudinal folds (Sruoga \& De Prins 2009 , figs 48,49$) \ldots \ldots \ldots \ldots \ldots \ldots \ldots$. . . . . . . . . Spatulata

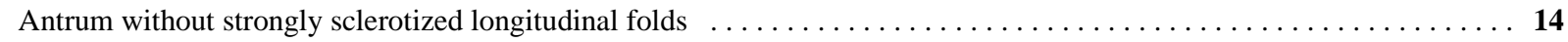
Colliculum about 3 times longer than wide; antrum long and weakly sclerotized (Sruoga \& De Prins 2011, figs 66-71) ....

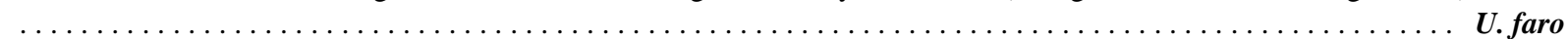
Colliculum as long as wide; antrum short and strongly sclerotized (Sruoga \& De Prins 2011, figs 85-88) . . . . U. tortuosa

* females of $U$. aculeata, U. crenata, U. cuspidis, U. gnoma, U. taeniata, and U. tantilla are unknown.

\section{Discussion}

In its long taxonomic history, Urodeta has remained an enigmatic and controversial genus. It is most probably a tropical genus with the highest species diversity in sub-saharan Africa. In this biogeographical region this genus is as species-rich as Elachista. Probably many more Urodeta species will be discovered in suitable tropical biotopes (Sruoga \& De Prins 2011; Landry 2011). This has become a general trend in the Gelechioidea studies: the numbers of species within gelechioid genera are greatly revised upwards once available specimens collected in the Afrotropics and deposited in the holdings of natural history museums are examined (Mey 2004, 2007; Krüger 2007b; Bidzilya 2010). The evolutionary success of Gelechioidea as a megadiverse group becomes even more evident when tropical taxa are considered, which will greatly change our perceptions based on the Palaearctic fauna.

The morphology of the four elachistine genera Elachista, Perittia, Stephensia and Urodeta were studied in detail to find their phylogenetic position within Gelechioidea (Kaila 1999, 2004, Kaila \& Sugisima 2011). Molecular characters are only known for the former three genera (Kaila et al. 2011). The monophyly of Urodeta in adult morphology is supported by one synapomorphy - cephalically directed orientation of the spines in the gnathos - and six homoplastic characters: i) the reduced pilifer; ii) short and straight labial palpomere II, iii) absence of styloconic sensillae in the proboscis; iv) oval shaped T2, v) distal margin of cucullus apically pointed, and vi) concave termen of valva. The status and the position of all elachistine genera within Gelechioidea (see Table 1) will require a great deal of revisionary work including detailed morphological and molecular studies. 
The inference from trends in described species that gelechioids possess a reverse latitudinal/elevational gradient "i. e., the highest known species numbers are found not in the tropics, but rather in temperate or even boreal zones... Even in tropics, the highest diversities for several gelechioid groups are found in montane regions" (Kaila et al. 2011: 802) cannot be confirmed by new Afrotropical gelechioid collecting data. Just a rough estimation of thousands of Gelechioidea species and specimens deposited at the collection of the RMCA suggests a very strong bias due to undersampling in the tropics. Furthermore, most gelechioid specimens and a great majority of gelechioid species have been collected in savanna biotopes and in low elevations. JDP's collecting experience is that in the East African savanna at low or mid elevations, Pyraloidea, Gelechioidea and Noctuoidea obviously dominate all other Lepidoptera superfamilies. This trend is supported by $\alpha$ and $\beta$-diversity measures in different biotopes of the Brandberg Massif in Namibia (Mey 2004, 2007). In a review of Afrotropical Gelechioidea: Blastobasidae Adamski et al. (2010: 2) also explicitly state that the collecting site "is located in semiarid savanna .....at $1650 \mathrm{~m}$ elevation ... The vegetation is characteristic of semiarid African savannas, predominantly grassy savanna bushland, with patches of woodland and open grassland." The remarkable diversity of Gelechioidea: Oecophoridae with an estimated 3500 species belonging to approximately 260 known genera has been recorded from both the drier lowland grassland biotopes and moist habitats of Australia (Common 1994, 1997, 2000; Nielsen et al. 1996). However, in the Neotropics an incredible species-richness of Cosmopterix Hübner, [1825] and Pebobs Hodges, 1978 (Gelechioidea: Cosmopterigidae) was found in biotopes of rather different elevations (Koster 2010). We, herewith, echo Kaila et al. (2011: 802) that the reverse latitudinal and elevational gradient of Gelechioidea diversity "might be caused by insufficient sampling and taxonomic study in the tropics".

The available fossil evidence suggests that the major diversification in Lepidoptera occurred during the Cretaceous and early Tertiary periods (Grimaldi \& Engel 2005; Krüger 2007a,b; Heikkilä et al. 2012; Sohn et al. 2012) while in some lepidopteran clades (Nymphalidae, for instance) the major lineages diverged during the late Oligocene, presuming that the extant species have diverged from their sister species-groups mainly during the late Miocene (Wahlberg \& Rubinoff 2011). As regards evolution and diversification of Lepidoptera in Africa, this crucial period [Cretaceous] coincides with the later stages in the fragmentation of Gondwana (ca. 120-60 Mya), and as a consequence of this, the Afrotropical moth fauna evolved mainly in isolation (Krüger 2007b), but with subsequently added immigrants arriving via bridges, which linked Africa and Eurasia during this period (Krüger 2007a). With 18 Afrotropical, two Australasian, and one Mediterranean species, Urodeta probably dispersed in the opposite direction, which resulted in this disjunct distribution pattern. With present knowledge Africa contains the highest diversity and the broadest range of Urodeta taxa, thus, allowing us to assume that this continent could be the region of origin of this genus. Hopefully, the already available advanced molecular methods might help to confirm/reject this assumption in the near future. The other hypothesis suggests that some groups of primitive moths (e.g. Micropterigidae) might have had a much wider distribution in the Mesozoic and Cenozoic and eventually survived in refuge areas in Southern Hemisphere continents (Mey 2011). Whether Urodeta might represent a Cenozoic relict is still controversial, but in a future study it would be challenging to determine the phylogenetic age of this lineage and shed some light on whether this age might be reconciled with the break up of the various parts of Gondwana.

\section{Acknowledgements}

JDP sincerely thanks The Research Foundation - Flanders for financing her study trip to the TMSA in Pretoria, South Africa and valuable consultations received from Lajos Vári and Martin Krüger. Both Lepidoptera curators Martin Krüger and Barbara Dombrowski are gratefully acknowledged for organizing the collecting trip to the Tswaing Nature Reserve, Gauteng Province, South Africa. Jurate \& Willy De Prins appreciate the hospitality and trust received from the administration of the nature reserve. We are grateful to Max Fernandez Alonso for the geological information on the Tswaing Crater. The taxonomic / morphological study of VS was funded by a grant (No. MIP-049/2011) received from the Research Council of Lithuania. Both authors are very grateful to David Lees for his very valuable comments and style improvements on an earlier draft of this paper. We cordially thank the reviewers for their suggestions. 


\section{References}

Adamski, D., Copeland, R.S., Miller, S.E., Hebert, P.D.N., Darrow, K. \& Luke, Q. (2010) A review of African Blastobasinae (Lepidoptera: Gelechioidea: Coleophoridae), with new taxa reared from native fruits in Kenya. Smithsonian Contributions to Zoology, 630, i-vi, 1-68.

Beccaloni, G., Scoble, M., Kitching, I., Simonsen, T., Robinson, G., Pitkin, B., Hine, A. \& Lyal, C. (Eds) (2005) The global Lepidoptera names index (LepIndex) Available from http://www.nhm.ac.uk/research-curation/research/projects/lepindex/ index.html (accessed 31 December 2011)

Bengtsson, B.Å. (1997) Scythrididae. In: Huemer, P., Karsholt, O. \& Lyneborg, L. (Eds) Microlepidoptera of Europe, 2, 1-301.

Bidzilya, O.V. (2010) A taxonomic review of the genera Parapsectris Meyrick, 1911 and Athrips Billberg, 1820 in Africa. Esperiana Memoir, 5, 341-408.

Boie, F. (1826) Generalübersicht der ornithologischen Ordnamen, Familien und Gattungen. Isis von Oken, 19, 969-982.

Cockell, C.S., Brandt, D., Hand, K. \& Lee, P.C. (2001) Microbial mats of the Tswaing impact crater: results of a South African exobiology expedition and implications for the search for biological molecules on Mars. $32^{\text {nd }}$ Lunar and Planetary Science Conference, 12-16 March 2001, Houston, Texas, USA, p. 1340.

Common, I.F.B. (1994) Oecophorine genera of Australia. I. The Wingia group (Lepidoptera: Oecophoridae) Monographs on Australian Lepidoptera, vol. 3. CSIRO Publishing, Melbourne, 390 pp.

Common, I.F.B. (1997) Oecophorine genera of Australia. II. The Chezala, Philobota and Eulechria groups (Lepidoptera: Oecophoridae) Monographs on Australian Lepidoptera, vol. 5. CSIRO Publishing, Melbourne, 407 pp.

Common, I.F.B. (2000) Oecophorine genera of Australia. III. The Barea group and unplaced genera (Lepidoptera: Oecophoridae) Monographs on Australian Lepidoptera, vol. 8. CSIRO Publishing, Melbourne, 469 pp.

de Joannis, J. (1902) Note sur un Microlépidoptère nouveau de Portugal. Bulletin de la Société entomologique de France, 1902, 230-232.

De Prins, J. \& De Prins, W. (2012) Afromoths, online database of Afrotropical moth species (Lepidoptera) Belgian Biodiversity Platform. Available from http://www.afromoths.net (accessed 13 January 2012)

Fletcher, T.B. (1929) A list of the generic names used for Microlepidoptera. Memoirs of the Department of Agriculture in India, 11, i-ix, 1-244.

Grimaldi, G. \& Engel, M.S. (2005) Evolution of the insects. Cambridge University Press, Cambridge, 755 pp.

Heikkilä, M., Kaila, L., Mutanen, M., Peña, C. \& Wahlberg, N. (2012) Cretaceous origin and repeated tertiary diversification of the redefined butterflies. Proceedings of the Royal Society, B, 279 (1731), 1093-1099 (available from doi: 10.1098/ rspb.2011.1430)

Hodges, R.W. (1978) Gelechioidea. Cosmopterigidae. The moths of America north of Mexico 6.1: ix + 166 pp, 6 pls. E.W. Classey, London.

Hodges, R.W. (1998) The Gelechioidea. In: Kristensen, N.P. (Ed.) Handbook of Zoology IV/35, Lepidoptera, Moths and Butterflies. Vol. 1. Evolution, Systematics, and Biogeography. Walter de Gruyter, Berlin, New York, pp. 131-158.

Hübner, J. (1816-1826) Verzeichniss bekannter Schmettlinge [recte Schmetterlinge]. J. Hübner Verlag, Augsburg, 431 pp., 72 pls.

International Commission on Zoological Nomenclature (1999) International Code of Zoological Nomenclature. Fourth Edition. The International Trust for Zoological Nomenclature, London, $306 \mathrm{pp}$.

Kaila, L. (1999) Phylogeny and classification of the Elachistidae s. s. (Lepidoptera, Gelechioidea) Systematic Entomology, 24, 139-169.

Kaila, L. (2004) Phylogeny of the superfamily Gelechioidea (Lepidoptera: Ditrysia): an exemplar approach. Cladistics, 20, 303-340.

Kaila, L. (2011) Elachistine Moths of Australia (Lepidoptera: Gelechioidea: Elachistidae) Monographs on Australian Lepidoptera, vol. 11. CSIRO Publishing, Melbourne. 443 pp.

Kaila, L. \& Sugisima, K. (2011) Phylogeny, subfamily definition and generic classification. In: Kaila, L. Elachistine moths of Australia (Lepidoptera: Gelechioidea: Elachistidae) Monographs on Australian Lepidoptera, vol. 11, CSIRO publishing, Melbourne, pp. 7-22.

Kaila, L., Mutanen, M. \& Nyman, T. (2011) Phylogeny of the mega-diverse Gelechioidea (Lepidoptera): Adaptations and determinants of success. Molecular Phylogenetics and Evolution, 61, 801-809.

Karsholt, O. \& van Nieukerken, E.J. (Eds) (2011) Lepidoptera, Moths. Fauna Europaea version 2.4. Available from http:// www.faunaeur.org (accessed 28 December 2011)

Koeberl, C., Storzer, D. \& Reimold, W.U. (1994) The age of the Saltpan impact crater, South Africa. Meteoritics, 29, 374-379.

Koster, J.C. (2010) The genera Cosmopterix Hübner and Pebobs Hodges in the New World with special attention to the Neotropical fauna (Lepidoptera: Cosmopterigidae) Zoologische Mededelingen Leiden, 84, 251-575, figs 1-271.

Koster, S. \& Sinev, S. (2003) Momphidae, Batrachedridae, Stathmopodidae, Agonoxenidae, Cosmopterigidae, Chrysopeleiidae. In: Huemer, P., Karsholt, O. \& Lyneborg, L. (Eds) Microlepidoptera of Europe, 5, 1-387.

Kristensen, N.P. (2003) Skeleton and muscles: adults. In: Kristensen, N.P. (Ed.), Lepidoptera, Moths and Butterflies. Vol. 2. Morphology, Physiology, and Development. Walter de Gruyter, Berlin, New York, pp. 39-122.

Krüger, M. (2007a) Composition and origin of the geometrid fauna (Lepidoptera) of the Sneeuberge, eastern Cape, with descriptions of new taxa. Annals of the Transvaal Museum, 44, 25-66. 
Krüger, M. (2007b) Composition and origin of the Lepidoptera faunas of southern Africa, Madagascar and Réunion (Insecta: Lepidoptera) Annals of the Transvaal Museum, 44, 123-178.

Landry, J.-F. (2011) Book review. Lauri Kaila (with contributions by Kazuhiro Sugisima) 2011. Elachistine Moths of Australia (Lepidoptera: Gelechioidea: Elachistidae) Nota lepidopterologica, 34, 111-114.

Leraut, P. (1980) Liste systématique et synonymique des Lépidoptères de France, Belgique et Corse. Alexanor, Supplément, $1-334$.

Leraut, P. (1997) Liste systématique et synonymique des Lépidoptères de France, Belgique et Corse (deuxième édition) Alexanor, Supplément, 1-526.

Lhomme, L. (1946-1963) Catalogue des Lépidoptères de France et de Belgique. Tineina. Le Carriol, par Douelle, Lot, pp. 489-1253.

Linnaeus, C. (1767) Systema Naturae per Regna Tria Naturae, secundum Classes, Ordines, Genera, Species, cum characteribus, differentiis, synonymis, Iocis. Tomus 1. Editio Decima tertia, ad Editionem duodecimam reformatam Holmiensem. Ioannis Thomae nob. de Trattnern, Vindobonae, 533-1327 pp.

Lopez-Vaamonde, C., Breman, F.C., Lees, D.C., Van Houdt, J. \& De Prins, J. (2012) Analysis of tissue dependent DNA yield for optimal sampling of micro-moths in large-scale biodiversity surveys. European Journal of Entomology, 109, 1-6.

Mey, W. (2004) Introduction: Research on Lepidoptera of Brandberg in Namibia (Insecta, Lepidoptera) In: Mey, W. (Ed.) The Lepidoptera of the Brandberg Massif in Namibia. Part 1. Esperiana Memoir, 1, 7-26.

Mey, W. (2007) Microlepidoptera: Smaller families. In: Mey, W. (Ed.) The Lepidoptera of the Brandberg Massif in Namibia. Part 2. Esperiana Memoir, 4, 9-30.

Mey, W. (2011) On the systematic position of Baltimartyria Skalski, 1995 and description of a new species from Baltic amber (Lepidoptera, Micropterigidae) ZooKeys, 130, 331-342.

Meyrick, E. (1881) Descriptions of Australian Micro-Lepidoptera. III. Tineina. The Proceedings of the Linnean Society of New South Wales, 5, 132-182.

Meyrick, E. (1913) Descriptions of South African Micro-Lepidoptera. IV. Annals of the Transvaal Museum, 3, $267-336$.

Meyrick, E. (1914a) Exotic Microlepidoptera, 1(7), 193-224.

Meyrick, E. (1914b) Descriptions of South African Micro-Lepidoptera. V. Annals of the Transvaal Museum, 4, $187-205$.

Meyrick, E. (1915) Revision of New Zealand Tineina. Transactions and Proceedings of the New Zealand Institute, 47, 205-244.

Meyrick, E. (1918) Descriptions of South African Micro-Lepidoptera. Annals of the Transvaal Museum, 6, 7-59.

Meyrick, E. (1921) Descriptions of South African Micro-Lepidoptera. Annals of the Transvaal Museum, 8, 49-148.

Meyrick, E. (1938) Pterophoridae, Tortricina and Tineina. Exploration du Parc National Albert. Mission G.F. de Witte (1933-1935), 14, 3-28 pp., 3 pls.

Nielsen, E.S., Edwards, E.D. \& Rangsi, T.V. (1996) Checklist of the Lepidoptera of Australia. Monographs on Australian Lepidoptera, vol. 4, CSIRO publishing, Melbourne, $529 \mathrm{pp}$.

Nye, I.W. \& Fletcher, D.S. (1991) The generic names of moths of the world. 6. Microlepidoptera. Natural History Museum Publications, London, xxix+368 pp.

Oberholster, P.J., Botha, A.M. \& Ashton, P.J. (2009) Appearance of new taxa: invertebrates, phytoplankton and bacteria in an alkaline, saline, meteorite crater lake, South Africa. Fundamental and Applied Limnology, 174, 271-282.

Parenti, U. (1988) About some African and Asiatic species of the family Elachistidae (Lepidoptera) described by E. Meyrick. Stapfia, 16, 185-198.

Passerin d'Entrèves, P. \& Roggero, A. (2007) Scythrididae. In: Heppner, J.B. (Ed.) Lepidopterorum Catalogus (new series) Fascicle 44. Association for Tropical Lepidoptera. Scientific Publishers, Gainesville, Washington, Hamburg, Lima, Taipei, Tokyo, 85 pp.

Pitkin, B. \& Jenkins, P. (2004) Butterflies and moths of the world. Generic names and their type-species. Available from http:// www.nhm.ac.uk/research-curation/research/projects/butmoth/ (accessed 31 December 2011)

Rebel, H. (1901) II Theil: Famil. Pyralidae -Micropterygidae. In: Staudinger, O. \& Rebel, H. Catalog der Lepidopteren des Palaearctischen Faunengebietes. R. Friedländer \& Sohn, Berlin, pp. 1-265.

Riedl, T. (1996) Momphidae. In: Karsholt, O. \& Razowski, J. (Eds) The Lepidoptera of Europe. A distributional checklist. Apollo Books, Stenstrup, pp. 95.

Robinson, G.S. (1976) The preparation of slides of Lepidoptera genitalia with special reference to the Microlepidoptera. Entomologist's Gazette, 27, 127-132.

Sohn, J.-C., Labandeira, C., Davis, D; \& Mitter, C. (2012) An annotated catalog of fossil and subfossil Lepidoptera (Insecta: Holometabola) of the world. Zootaxa, 3286, 1-132.

Sruoga, V. \& De Prins, J. (2009) The Elachistinae (Lepidoptera: Elachistidae) of Kenya with descriptions of eight new species. Zootaxa, 2172, 1-31.

Sruoga, V. \& De Prins, J. (2011) New species of Elachistinae (Lepidoptera: Elachistidae) from Cameroon and the Democratic Republic of the Congo. Zootaxa, 3008, 1-32.

Stainton, H.T. (1848) Description of three undescribed British species of the genus Aphelosetia. The Zoologist: a popular miscellany of Natural History, 6, 2164-2165.

Stainton, H.T. (1849) An attempt at a systematic catalogue of the British Tineidae \& Pterophoridae. John van Voorst, London, iv $+32 \mathrm{pp}$. 
Stainton, H.T. (1854) Insecta Britannica. Lovell Reeve, London, viii+313 pp., 10 pls.

Stainton, H.T. (1855) The Natural History of the Tineina. Volume I. Nepticula. Part I. Cemiostoma. Part I. John van Voorst, London, xv+328 pp., pls i-vii (Nepticula), i (Cemiostoma)

Stainton, H.T. (1857) The Natural History of the Tineina. Volume II. Lithocolletis. Part I. John van Voorst, London, vii+317 pp., i-viii pls.

Stainton, H.T. (1858a) The Natural History of the Tineina. Volume III. Elachista. Part I. Tischeria. Part I. John van Voorst, London, vii+269 pp., i-vii (Elachista), i (Tischeria) pls.

Stainton, H.T. (1858b) On the aberrant species hitherto placed in the genus Elachista. The Transactions of the Entomological Society of London, new series, 4, 267-271.

Stainton, H.T. (1859) The Natural History of the Tineina. Volume IV. Coleophora. Part I. John van Voorst, London, vii+292 pp., i-viii pls.

Stainton, H.T. (1860) The Natural History of the Tineina. Volume V. Coleophora. Part II. John van Voorst, London, vii+228 pp., ix-xvi pls.

Stainton, H.T. (1861) The Natural History of the Tineina. Volume VI. Depressaria. Part I. John van Voorst, London, vii+283 pp., i-viii pls.

Stainton, H.T. (1862) The Natural History of the Tineina. Volume VII. Bucculatrix. Part I. Nepticula. Part II. John van Voorst, London, vii+251 pp., i-iv (Bucculatrix), viii-xi (Nepticula) pls.

Stainton, H.T. (1864) The Natural History of the Tineina. Volume VIII. Gracilaria [recte Gracillaria]. Part I. Ornix. Part I. John van Voorst, London, vii+315 pp., i-v (Gracillaria), i-iii (Ornix) pls.

Stainton, H.T. (1865) The Natural History of the Tineina. Volume IX. Gelechia. Part I. John van Voorst, London, 276 pp., i-viii pls.

Stainton, H.T. (1867) The Natural History of the Tineina. Volume X. Gelechia. Part II. John van Voorst, London, ix +304 pp., ix-xvi pls.

Stainton, H.T. (1869) The Tineina of Southern Europe. John van Voorst, London. viii+370 pp.

Stainton, H.T. (1870a) The Natural History of the Tineina. Volume XI. John van Voorst, London, xi +330 pp., i-viii pls.

Stainton, H.T. (1870b) The Natural History of the Tineina. Volume XII. John van Voorst, London, 259 pp., i-viii pls.

Stainton, H.T. (1873) The Natural History of the Tineina. Volume XIII. John van Voorst, London, 377 pp., i-viii pls.

Staudinger, O. (1859) Diagnosen nebst kurzen Beschreibungen neuer andalusischer Lepidopteren. Entomologische Zeitung [Entomologischer Verein zu Stettin], 211-259.

Traugott-Olsen, E. \& Schmidt Nielsen, E. (1977) The Elachistidae (Lepidoptera) of Fennoscandia and Denmark. Fauna Entomologica Scandinavica, 6, 1-299.

Treitschke, F. (1833) Die Schmetterlinge von Europa. Neunter Band. Zweyte Abtheilung. Schaben. Geistchen. G. Hypsolopha-Orneodes. Ernst Fleischer, Leipzig, 294 pp.

van Nieukerken, E.J., Kaila, L., Kitching, I.J., Kristensen, N.P., Lees, D.C., Minet, J., Mitter, C., Mutanen, M., Regier, J.C., Simonsen, T.J., Wahlberg, N., Yen, S.-H., Zahiri, R., Adamski, D., Baixeras, J., Bartsch, D., Bengtsson, B.Å., Brown, J.W., Rae Bucheli, S., Davis, D.R., De Prins, J., De Prins, W., Epstein, M.E., Gentili-Poole, P., Gielis, C., Hättenschwiler, P., Hausmann, A., Holloway, J.D., Kallies, A., Karsholt, O., Kawahara, A.Y., Koster, S.(J.C.), Kozlov, M.V., Lafontaine, J.D., Lamas, G., Landry, J.-F., Lee, S., Nuss, M., Park, K.-T., Penz, C., Rota, J., Schintlmeister, A., Schmidt, B.C., Sohn, J.-C., Solis, M.A., Tarmann, G.M., Warren, A.D., Weller, S., Yakovlev, R.V., Zolotuhin, V.V. \& Zwick, A. Order Lepidoptera Linnaeus, 1758. In: Zhang, Z.-Q. (Ed.) (2011) Animal biodiversity: An outline of higher-level classification and survey of taxonomic richness. Zootaxa, 3148, 212-221.

Vári, L., Kroon, D. M. \& Krüger, M. (2002) Classification and Checklist of the species of Lepidoptera recorded in Southern Africa. Simple Solutions, Chatswood, xxi+384 pp.

Verschuren, D., Cocquyt, C., Tibby, J., Roberts, C.N. \& Leavitt, P.R. (1999) Long-term dynamics of algal and invertebrate communities in a small, fluctuating tropical soda lake. Limnology and Oceanography, 44, 1216-1231.

Vives Moreno, A. (1991) Catalogo sistematico y sinonimico de los lepidopteros de la peninsula Iberica y Baleares (Insecta: Lepidoptera). Grafur, s.a., Madrid, 378 pp.

Vives Moreno, A. (1994) Catalogo sistematico y sinonimico de los lepidopteros de la peninsula Iberica y Baleares (Insecta: Lepidoptera) (Segunda Parte). V.A. Impresores, s.a., Madrid, 775 pp.

Wahlberg, N. \& Rubinoff, D. (2011) Vagility across Vanessa (Lepidoptera: Nymphalidae): mobility in butterfly species does not inhibit the formation and persistence of isolated sister taxa. Systematic Entomology, 36, 362-370.

Walraven, F., Armstrong, R.A. \& Kruger, F.J. (1990) A chronostratigraphic framework for the north-central Kaapvaal cration, the Bushveld Complex and the Vredefort structure. Tectonophysics, 171, $23-48$.

Wocke, M. F. In: Heinemann, H. \& Wocke, M.F. [1876] (1877) Schmetterlinge Deutschlands und der Schweiz. Zweite Abtheilung. Kleinschmetterlinge. Band II. Die Motten und Federmotten. Heft II. C.A. Schwetschke und Sohn, Braunschweig, vi+390-825, identification key after separate pagination, 1-102.

Zeller, P.C. (1848) Die Gattungen der mit Augendeckeln versehenen blattminirenden Schaben. Linnaea Entomologica, 3, $248-344$.

Zerkowitz, A. (1946) The Lepidoptera of Portugal. Journal of the New York Entomological Society, 54, 115-165. 